\title{
Analysis of the nodal stresses in pile caps
}

\section{Análise das tensões nodais em blocos sobre estacas}
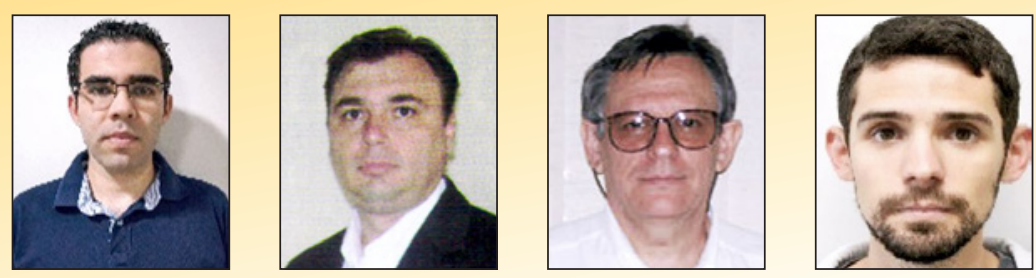

M. A. TOMAZ a eng.matomaz@gmail.com

R. G. DELALIBERA delalibera@ufu.br

J. S. GIONGO b jsgiongo@sc.usp.br

V. F. GONÇALVES a vitorfrg@gmail.com

\section{Abstract}

Pile caps can be dimensioned using, preferably, plastic models (strut-and-tie) and models based on the flexion theory. In order to analyze the behavior of the stresses in the lower and upper nodal regions of the cap, a theoretical analysis of the experimental results found by several researchers was made. There was a discrepancy in the results obtained and, as a result, a critical analysis carried out and a new methodology for the verification of the nodal stress near the upper zone, based on the multiaxial behavior of the concrete, is suggested.

Keywords: pile caps, strut-and-tie model, nodal stress.

\section{Resumo}

Blocos sobre estacas podem ser dimensionados utilizando-se, preferencialmente, modelos plásticos (bielas e tirantes) e modelos baseados na teoria da flexão. Com o intuito de analisar o comportamento das tensões nas regiões nodais inferior e superior do bloco, fez-se uma análise teórica dos resultados dos ensaios experimentais realizados por diversos pesquisadores. Observaram-se divergências nos resultados e, em função disto, foi feita uma análise crítica que permitiu a sugestão de uma nova metodologia para a verificação das tensões nodais junto a zona nodal superior, baseada no comportamento multiaxial do concreto.

Palavras-chave: blocos sobre estacas, modelo de bielas e tirantes, tensões nodais. 


\section{Introduction}

For pile caps design it is possible to adopt three-dimensional calculation models (linear or not) and strut-and-tie models, the latter being the most indicated because it considers regions of stress discontinuities.

The strut-and-tie model is a method based on the lower bound theory, using the concept of plasticity and consists of the design by idealizing a space truss, composed by connecting struts (representing compression fields), ties (representing tensile fields) and nodes (volume of concrete with the purpose of transfering the stress between connecting struts and ties, and between cap and piles and column and cap). The design consists on verifying the stress on the contact region between the column/pile cap (upper nodal area) and cap/piles (lower nodal area).

Blévot [1] studied the behavior of caps on three and four piles, proposing equation for the models. Blévot and Frémy [2] then extended the study of pile caps, which led them to propose an interval to the angle between the strut and the horizontal axis, in order to ensure that the pile cap is safe. In addition, the authors have suggested maximum values for the stress on the nodal areas. Due to its importance and comprehensiveness, these works have guided all subsequent studies about pile caps.

Since then, the subject has been widely studied and several researchers have proposed different values for the limits of nodal stresses, as well as different ways of applying the strut-and-tie model.

\subsection{Justification}

The ABNT NBR 6118:2014 [3] does not present specific criteria for the pile caps design, however, it indicates the use of the strutand-tie model for describing well the internal structural behavior of pile caps.

According to the ABNT NBR 6118:2014 [3], the stresses that arise in the nodal areas should be limited, however, there are many divergences in relation to the criteria adopted by the Brazilian norms and international norms. Likewise, there are also divergences in relation to defining the area and shape of the lower and upper nodal zones.

The Brazilian norm provides parameters for stress verification but it does not specify which strut-and-tie model should be adopted, allowing the engineer to freely choose the most suitable model. Thus, this article is justified by the uncertainties still existing on the design and verification of pile caps.

\subsection{Objective}

The purpose of this work was to analyze the nodal stresses obtained through experimental tests, comparing them with the existing normative limits. Methods proposed by different authors for obtaing the nodal stresses were used. Finally, it was aimed to present a criterion considering the multiaxial effect of the concrete near the upper nodal zone.

\section{Experimental results used}

Firstly, the largest possible number of experimental data was collected regarding the geometric and physical properties of the pile caps (dimensions, distance between pile centers, pile and column cross sections, force applied to the column in which the first crack arose and column reinforcement rates) and the ultimate forces for each cap tested and their respective concrete compressive strength $\left(f_{\mathrm{c}}\right)$. Only the pile caps with monolithic connections were considered, in other words, caps with calyx foundation were discarded.

Adebar et al. [4] tested six caps, five of which were supported on four piles and only one supported on six piles, see Figure [1]. The caps on four piles have hexagonal geometry and therefore has two directions (hence the indication of values in the $x$ and $y$ directions). Since model $C$ has six piles, the indication of $\theta_{x}$ refers to the angle of strut related to the most remote pile, and $\theta_{y}$ refers to the angle of the strut related to the nearest pile.

The adopted angles were those described as being the observed
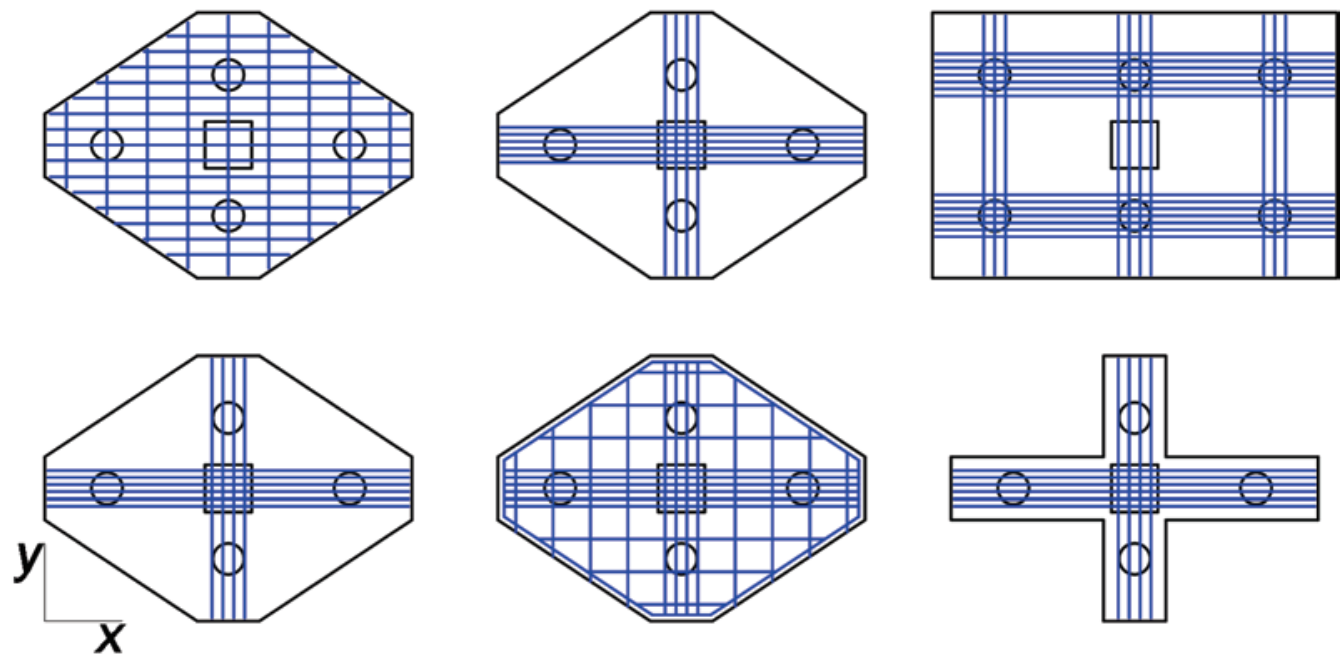

Figure 1

Models tested by Adebar et al. [4] 


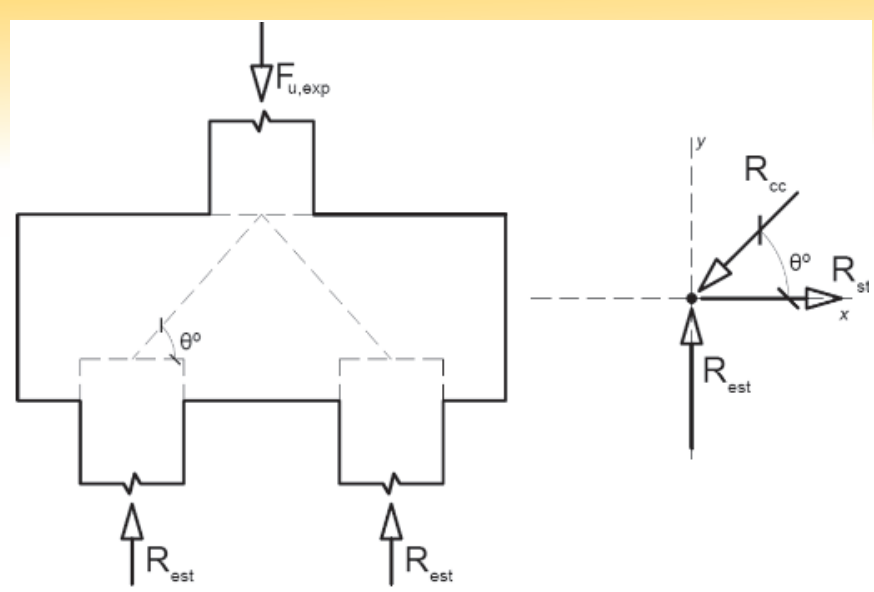

Figure 2

Equilibrium of forces in the lower nodal region for $\mathrm{R}_{\mathrm{st}}$ calculation (resulting force in the tie) and $\mathrm{R}_{\mathrm{cc}}$ (resulting force in the strut)

angles in the tests. In the cases in which it was not possible to obtain the angle experimentally, a line was drawn by joining the center of gravity of the cross section of the column to the center of gravity of the cross section of the pile. It is important to note that this hypothesis of considering the angle of inclination of the strut in relation to the horizontal plane differs from the model proposed by Blévot and Frémy [2]. The french researchers consider that the beginning of the strut, next to the upper nodal zone, occurs at $1 / 4$ of the column size in the considered direction, measured from the column face.

The collected data for the analysis was extracted from the works of Adebar et al. [4], Mautoni [5], Fusco [6], Chan and Poh [7], Miguel [8], Delalibera and Giongo [9], Barros [10], Munhoz [11], Mesquita [12] and Cao and Bloodworth [13] and are shown in Tables [1] to [10].

It is also important to clarify that the experimental tests of Blévot and Frémy [2] were not considered in this work due to the large number of tests. Therefore, the authors of this article decided to elaborate an article similar to this one, considering only the tests of Blévot and Frémy [2].

The purpose of this study was to calculate the nodal stresses, using three different models: Blévot and Frémy [2], Schlaich and Schäfer [14] and Fusco [15]. The models are based on the forces acting on the struts and/or the piles reactions. To calculate such forces, the equilibrium of the nodal region was made as it is shown in Figure [2]. The presence of a bending moment at the base of the column was studied by Delalibera and Giongo [9].

\section{Table 1}

Properties of the pile caps analyzed by Mautoni [5]

\begin{tabular}{|c|c|c|c|c|c|c|c|c|c|}
\hline $\begin{array}{l}\text { Tested } \\
\text { model }\end{array}$ & $\begin{array}{c}\text { Pile } \\
\text { number }\end{array}$ & $\begin{array}{l}\text { Height } \\
(\mathrm{cm})\end{array}$ & $\begin{array}{l}\text { Length } \\
(\mathrm{cm})\end{array}$ & $\begin{array}{l}\text { Pile section } \\
(\mathrm{cm} \times \mathrm{cm})\end{array}$ & $\begin{array}{l}\text { Distance } \\
\text { between } \\
\text { piles }(\mathrm{cm})\end{array}$ & $\begin{array}{l}\text { Column } \\
\text { section } \\
(\mathrm{cm} \times \mathrm{cm})\end{array}$ & $\begin{array}{l}\text { Column } \\
\text { reinforcement } \\
\text { rate }(\%)\end{array}$ & $\theta\left({ }^{\circ}\right)$ & $\begin{array}{c}f_{c, \exp } \\
(\mathrm{MPa})\end{array}$ \\
\hline B1-1 & 2 & 23 & 50 & $10 \times 15$ & 31 & $15 \times 15$ & - & 56.02 & 21.50 \\
\hline B2-1 & 2 & 23 & 50 & $10 \times 15$ & 31 & $15 \times 15$ & - & 26.02 & 21.50 \\
\hline B1-2 & 2 & 23 & 50 & $10 \times 15$ & 32 & $15 \times 15$ & - & 55.18 & 15.00 \\
\hline B2-2 & 2 & 23 & 50 & $10 \times 15$ & 32 & $15 \times 15$ & - & 55.18 & 15.00 \\
\hline B1-A & 2 & 23 & 50 & $10 \times 15$ & 32 & $15 \times 15$ & - & 55.18 & 32.30 \\
\hline B2-A & 2 & 23 & 50 & $10 \times 15$ & 32 & $15 \times 15$ & - & 55.18 & 32.30 \\
\hline B1-B & 2 & 20 & 50 & $10 \times 15$ & 32 & $15 \times 15$ & - & 51.34 & 32.00 \\
\hline B2-B & 2 & 20 & 50 & $10 \times 15$ & 32 & $15 \times 15$ & - & 51.34 & 32.00 \\
\hline B1-4A & 2 & 20 & 50 & $10 \times 15$ & 32 & $15 \times 15$ & - & 51.34 & 29.50 \\
\hline B2-4A & 2 & 20 & 50 & $10 \times 15$ & 32 & $15 \times 15$ & - & 51.34 & 29.50 \\
\hline B1-4B & 2 & 20 & 50 & $10 \times 15$ & 32 & $15 \times 15$ & - & 51.34 & 27.80 \\
\hline B2-4B & 2 & 20 & 50 & $10 \times 15$ & 32 & $15 \times 15$ & - & 51.34 & 27.80 \\
\hline B1-4C & 2 & 20 & 50 & $10 \times 15$ & 32 & $15 \times 15$ & - & 51.34 & 22.20 \\
\hline B2-4C & 2 & 20 & 50 & $10 \times 15$ & 32 & $15 \times 15$ & - & 51.34 & 22.20 \\
\hline D1 & 2 & 21 & 50 & $10 \times 15$ & 35 & $15 \times 15$ & - & 50.19 & 22.90 \\
\hline D2 & 2 & 21 & 50 & $10 \times 15$ & 35 & $15 \times 15$ & - & 50.19 & 22.90 \\
\hline $\mathrm{Fl}$ & 2 & 20 & 50 & $10 \times 15$ & 40 & $15 \times 15$ & - & 45.00 & 23.60 \\
\hline F2 & 2 & 20 & 50 & $10 \times 15$ & 40 & $15 \times 15$ & - & 45.00 & 23.60 \\
\hline $\mathrm{El}$ & 2 & 20 & 50 & $10 \times 15$ & 45 & $15 \times 15$ & - & 41.63 & 19.50 \\
\hline G1 & 2 & 20 & 50 & $10 \times 15$ & 45 & $15 \times 15$ & - & 41.63 & 24.30 \\
\hline
\end{tabular}

Note: all pile caps were $15 \mathrm{~cm}$ wide.

\section{Table 2}

Properties of the pile caps analyzed by Fusco [6]

\begin{tabular}{cccccccccc}
\hline $\begin{array}{c}\text { Tested } \\
\text { model }\end{array}$ & $\begin{array}{c}\text { Pile } \\
\text { number }\end{array}$ & $\begin{array}{c}\text { Height } \\
(\mathrm{cm})\end{array}$ & $\begin{array}{c}\text { Length } \\
(\mathrm{cm})\end{array}$ & $\begin{array}{c}\text { Pile section } \\
(\mathbf{c m \times c m})\end{array}$ & $\begin{array}{c}\text { Distance } \\
\text { between } \\
\text { piles }(\mathbf{c m})\end{array}$ & $\begin{array}{c}\text { Column } \\
\text { section } \\
(\mathbf{c m} \times \mathbf{c m})\end{array}$ & $\begin{array}{c}\text { Column } \\
\text { reinforcement } \\
\text { rate }(\%)\end{array}$ & $\begin{array}{c}\theta\left({ }^{\circ}\right) \\
(\mathrm{m})\end{array}$ \\
\hline A-1 & 2 & 250 & 800 & $10 \times 10$ & 500 & $20 \times 20$ & - & 48.00 \\
B-1 & 2 & 250 & 800 & $10 \times 10$ & 500 & $20 \times 20$ & - & 27.20 \\
C-1 & 2 & 250 & 800 & $10 \times 10$ & 500 & $20 \times 20$ & - & 48.00 & 23.90 \\
\hline
\end{tabular}


By balancing the forces in the $\mathrm{x}$ and $\mathrm{y}$ directions, the following equations are obtained:

$\mathrm{R}_{\text {est }}=\frac{\mathrm{F}_{\mathrm{u}, \mathrm{exp}}}{\mathrm{n}^{\circ} \text { of piles }}$

$\mathrm{R}_{\mathrm{est}}=\mathrm{R}_{\mathrm{Cc}} \cdot \sin (\theta)$

$\mathrm{R}_{\mathrm{St}}=\mathrm{R}_{\mathrm{CC}} \cdot \cos (\theta)$

in which:

$\mathrm{F}_{\mathrm{u}, \mathrm{exp}}$ is the ultimate experimental force applied to the column;

$\mathrm{R}_{\text {est }}$ is the reaction of $\mathrm{F}_{\mathrm{u} \text { exp }}$ on each pile;

$R_{c c}$ is the resulting force on compressed concrete (resulting force on the strut);

$R_{s t}$ is the resulting force on the reinforcing steel (resulting force on the tie) and;

$\theta$ is the strut angle of inclination.

Equations [1] and [2] were used to determine the stress acting on the struts and on the nodes according to each one of the aforementioned models.

\section{Table 3}

Properties of the pile caps analyzed by Adebar et al. [4]

\begin{tabular}{|c|c|c|c|c|c|c|c|c|c|c|c|}
\hline $\begin{array}{l}\text { Tested } \\
\text { model }\end{array}$ & $\begin{array}{c}\text { Pile } \\
\text { number }\end{array}$ & $\begin{array}{l}\text { Height } \\
(\mathrm{cm})\end{array}$ & $\begin{array}{l}\text { Length } \\
(\mathrm{cm})\end{array}$ & $\begin{array}{c}\text { Pile } \\
\text { diameter } \\
(\mathrm{cm})\end{array}$ & $\begin{array}{c}\text { Distance } \\
\text { between } \\
\text { piles x } \\
(\mathrm{cm})\end{array}$ & $\begin{array}{c}\text { Distance } \\
\text { between } \\
\text { piles y } \\
(\mathrm{cm})\end{array}$ & $\begin{array}{l}\text { Column } \\
\text { section } \\
(\mathrm{cm} \times \mathrm{cm})\end{array}$ & $\begin{array}{l}\text { Column } \\
\text { reinforcement } \\
\text { rate }(\%)\end{array}$ & $\theta_{x}\left({ }^{\circ}\right)$ & $\theta_{x}\left({ }^{\circ}\right)$ & $\begin{array}{c}f_{c, \exp } \\
(\mathrm{MPa})\end{array}$ \\
\hline A & 4 & 60 & - & 20 & 156 & 90 & $30 \times 30$ & 0.891 & 37.57 & 53.13 & 24.80 \\
\hline B & 4 & 60 & - & 20 & 156 & 90 & $30 \times 30$ & 0.891 & 37.57 & 53.13 & 24.80 \\
\hline C & 6 & 60 & 260 & 20 & 90 & 90 & $30 \times 30$ & 0.891 & 30.81 & 53.13 & 27.10 \\
\hline$D$ & 4 & 60 & - & 20 & 156 & 90 & $30 \times 30$ & 0.891 & 37.57 & 53.13 & 30.30 \\
\hline E & 4 & 60 & - & 20 & 156 & 90 & $30 \times 30$ & 0.891 & 37.57 & 53.13 & 41.10 \\
\hline $\mathrm{F}$ & 4 & 60 & - & 20 & 156 & 90 & $30 \times 30$ & 0.891 & 37.57 & 53.13 & 30.30 \\
\hline
\end{tabular}

Note: Pile cap C was a rectangular pile cap $170 \mathrm{~cm}$ wide, the other pile caps had hexagonal geometry according to Figure [1].

\section{Table 4}

Properties of the pile caps analyzed by Chan and Poh [7]

\begin{tabular}{|c|c|c|c|c|c|c|c|c|c|}
\hline $\begin{array}{l}\text { Tested } \\
\text { model }\end{array}$ & $\begin{array}{c}\text { Pile } \\
\text { number }\end{array}$ & $\begin{array}{l}\text { Height } \\
(\mathrm{cm})\end{array}$ & $\begin{array}{l}\text { Length } \\
(\mathrm{cm})\end{array}$ & $\begin{array}{l}\text { Pile section } \\
(\mathrm{cm} \times \mathrm{cm})\end{array}$ & $\begin{array}{c}\text { Distance } \\
\text { between } \\
\text { piles }(\mathrm{cm})\end{array}$ & $\begin{array}{l}\text { Column } \\
\text { section } \\
(\mathrm{cm} \times \mathrm{cm})\end{array}$ & $\begin{array}{l}\text { Column } \\
\text { reinforcement } \\
\text { rate }(\%)\end{array}$ & $\theta\left({ }^{\circ}\right)$ & $\begin{array}{c}f_{c, \exp } \\
(\mathrm{MPa})\end{array}$ \\
\hline$A$ & 4 & 40 & 100 & $15 \times 15$ & 60 & $20 \times 20$ & - & 43.31 & 39.70 \\
\hline B & 4 & 40 & 100 & $15 \times 15$ & 60 & $20 \times 20$ & - & 43.31 & 38.30 \\
\hline C & 4 & 30 & 100 & $15 \times 15$ & 60 & $20 \times 20$ & - & 35.26 & 36.40 \\
\hline
\end{tabular}

Note: all pile caps were $100 \mathrm{~cm}$ wide.

\section{Table 5}

Properties of the pile caps analyzed by Mautoni [5]

\begin{tabular}{|c|c|c|c|c|c|c|c|c|c|}
\hline $\begin{array}{l}\text { Tested } \\
\text { model }\end{array}$ & $\begin{array}{c}\text { Pile } \\
\text { number }\end{array}$ & $\begin{array}{l}\text { Height } \\
(\mathrm{cm})\end{array}$ & $\begin{array}{l}\text { Length } \\
(\mathrm{cm})\end{array}$ & $\begin{array}{l}\text { Pile section } \\
(\mathrm{cm} \times \mathrm{cm})\end{array}$ & $\begin{array}{l}\text { Distance } \\
\text { between } \\
\text { piles }(\mathrm{cm})\end{array}$ & $\begin{array}{l}\text { Column } \\
\text { section } \\
(\mathrm{cm} \times \mathrm{cm})\end{array}$ & $\begin{array}{l}\text { Column } \\
\text { reinforcement } \\
\text { rate (\%) }\end{array}$ & $\theta\left({ }^{\circ}\right)$ & $\begin{array}{l}f_{c, e x p} \\
(\mathrm{MPa})\end{array}$ \\
\hline $\mathrm{B} 20 \mathrm{~A} 1 / 1$ & 3 & 60 & - & 20 & 96 & $35 \times 35$ & 9.816 & 52.00 & 27.40 \\
\hline B20A1/2 & 3 & 60 & - & 20 & 96 & $35 \times 35$ & 9.816 & 52.00 & 33.00 \\
\hline B20A2 & 3 & 60 & - & 20 & 96 & $35 \times 35$ & 9.816 & 52.00 & 35.50 \\
\hline B20A3 & 3 & 60 & - & 20 & 96 & $35 \times 35$ & 9.816 & 52.00 & 37.90 \\
\hline B20A4 & 3 & 60 & - & 20 & 96 & $35 \times 35$ & 9.816 & 52.00 & 35.60 \\
\hline B30A1 & 3 & 60 & - & 30 & 96 & $35 \times 35$ & 9.816 & 52.00 & 31.00 \\
\hline B30A2 & 3 & 60 & - & 30 & 96 & $35 \times 35$ & 9.816 & 52.00 & 40.30 \\
\hline B30A3 & 3 & 60 & - & 30 & 96 & $35 \times 35$ & 9.816 & 52.00 & 24.50 \\
\hline B30A4 & 3 & 60 & - & 30 & 96 & $35 \times 35$ & 9.816 & 52.00 & 24.60 \\
\hline
\end{tabular}




\subsection{Calculation of the acting stresses}

Blévot and Frémy [2] present simple formulation for the calculation of the nodal stresses. The model contemplates only the value of the force applied to the column, the column cross-sectional area and the pile crosssectional area, both projected in the direction of the strut, see Figure [3].

Table 6

Properties of the pile caps analyzed by Delalibera and Giongo [9]

\begin{tabular}{|c|c|c|c|c|c|c|c|c|c|}
\hline $\begin{array}{l}\text { Tested } \\
\text { model }\end{array}$ & $\begin{array}{c}\text { Pile } \\
\text { number }\end{array}$ & $\begin{array}{l}\text { Height } \\
(\mathrm{cm})\end{array}$ & $\begin{array}{l}\text { Length } \\
(\mathrm{cm})\end{array}$ & $\begin{array}{l}\text { Pile section } \\
(\mathrm{cm} \times \mathrm{cm})\end{array}$ & $\begin{array}{l}\text { Distance } \\
\text { between } \\
\text { piles }(\mathrm{cm})\end{array}$ & $\begin{array}{l}\text { Column } \\
\text { section } \\
(\mathrm{cm} \times \mathrm{cm})\end{array}$ & $\begin{array}{l}\text { Column } \\
\text { reinforcement } \\
\text { rate }(\%)\end{array}$ & $\theta\left({ }^{\circ}\right)$ & $\begin{array}{c}f_{c, \exp } \\
(\mathrm{MPa})\end{array}$ \\
\hline B35P25E25 and 0 & 2 & 35 & 117.50 & $25 \times 25$ & 62.50 & $25 \times 25$ & 1.0053 & 45.00 & 40.60 \\
\hline B35P25E25 and 2,5 & 2 & 35 & 117.50 & $25 \times 25$ & 62.50 & $25 \times 25$ & 1.0053 & 45.00 & 40.60 \\
\hline B35P25E25 and $\mathrm{O}_{\text {Aswc }}$ & 2 & 35 & 117.50 & $25 \times 25$ & 62.50 & $25 \times 25$ & 1.0053 & 45.00 & 32.80 \\
\hline B35P25E25 and OA $\mathrm{As}_{\text {swo }}$ & 2 & 35 & 117.50 & $25 \times 25$ & 62.50 & $25 \times 25$ & 1.0053 & 45.00 & 32.80 \\
\hline B35P25E25 and OCG & 2 & 35 & 117.50 & $25 \times 25$ & 62.50 & $25 \times 25$ & 1.0053 & 45.00 & 28.90 \\
\hline B45P25E25 and 0 & 2 & 45 & 117.50 & $25 \times 25$ & 62.50 & $25 \times 25$ & 2.7489 & 54.50 & 31.00 \\
\hline B45P25E25 and 5 & 2 & 45 & 117.50 & $25 \times 25$ & 62.50 & $25 \times 25$ & 2.7489 & 54.50 & 31.00 \\
\hline B45P25E25 and OA ${ }_{s w C}$ & 2 & 45 & 117.50 & $25 \times 25$ & 62.50 & $25 \times 25$ & 2.7489 & 54.50 & 32.40 \\
\hline B45P25E25 and OA $\mathrm{Aw}_{\text {swo }}$ & 2 & 45 & 117.50 & $25 \times 25$ & 62.50 & $25 \times 25$ & 2.7489 & 54.50 & 32.40 \\
\hline B45P25E25 and OCG & 2 & 45 & 117.50 & $25 \times 25$ & 62.50 & $25 \times 25$ & 2.7489 & 54.50 & 28.90 \\
\hline B35P50E25 and 0 & 2 & 35 & 117.50 & $25 \times 25$ & 62.50 & $25 \times 50$ & 0.87965 & 53.10 & 35.80 \\
\hline B35P50E25 and 12.5 & 2 & 35 & 117.50 & $25 \times 25$ & 62.50 & $25 \times 50$ & 0.87965 & 53.10 & 35.10 \\
\hline B45P50E25 and 0 & 2 & 45 & 117.50 & $25 \times 25$ & 62.50 & $25 \times 50$ & 1.3745 & 61.80 & 35.80 \\
\hline B45P50E25 and 12.5 & 2 & 45 & 117.50 & $25 \times 25$ & 62.50 & $25 \times 50$ & 1.3745 & 61.80 & 35.10 \\
\hline
\end{tabular}

Note: the pile caps were $25 \mathrm{~cm}$ wide.

\section{Table 7}

Properties of the pile caps analyzed by Barros [10]

\begin{tabular}{cccccccccc}
\hline $\begin{array}{c}\text { Tested } \\
\text { model }\end{array}$ & $\begin{array}{c}\text { Pile } \\
\text { number }\end{array}$ & $\begin{array}{c}\text { Height } \\
(\mathbf{c m})\end{array}$ & $\begin{array}{c}\text { Length } \\
(\mathbf{c m})\end{array}$ & $\begin{array}{c}\text { Pile section } \\
(\mathbf{c m} \times \mathbf{c m})\end{array}$ & $\begin{array}{c}\text { Distance } \\
\text { between } \\
\text { piles }(\mathbf{c m})\end{array}$ & $\begin{array}{c}\text { Column } \\
\text { section } \\
(\mathbf{c m} \times \mathbf{c m})\end{array}$ & $\begin{array}{c}\text { Column } \\
\text { reinforcement } \\
\text { rate }(\%)\end{array}$ & $\begin{array}{c}\theta\left({ }^{\circ}\right) \\
(\mathrm{MPa})\end{array}$ \\
\hline $\mathrm{SR} / \mathrm{M} 1$ & 2 & 70 & 185 & $15 \times 15$ & 125 & $15 \times 15$ & 2.181 & 37.30 & 33.10 \\
$\mathrm{CR} / \mathrm{M} 8$ & 2 & 61 & 170 & $15 \times 15$ & 110 & $15 \times 15$ & 2.181 & 66.50 & 33.10 \\
\hline
\end{tabular}

Note: the pile caps were $60 \mathrm{~cm}$ wide.

Table 8

Properties of the pile caps analyzed by Munhoz [11]

\begin{tabular}{|c|c|c|c|c|c|c|c|c|c|}
\hline $\begin{array}{l}\text { Tested } \\
\text { model }\end{array}$ & $\begin{array}{c}\text { Pile } \\
\text { number }\end{array}$ & $\begin{array}{l}\text { Height } \\
(\mathrm{cm})\end{array}$ & $\begin{array}{l}\text { Length } \\
(\mathrm{cm})\end{array}$ & $\begin{array}{l}\text { Pile section } \\
(\mathrm{cm} \times \mathrm{cm})\end{array}$ & $\begin{array}{l}\text { Distance } \\
\text { between } \\
\text { piles }(\mathrm{cm})\end{array}$ & $\begin{array}{l}\text { Column } \\
\text { section } \\
(\mathrm{cm} \times \mathrm{cm})\end{array}$ & $\begin{array}{l}\text { Column } \\
\text { reinforcement } \\
\text { rate }(\%)\end{array}$ & $\theta\left({ }^{\circ}\right)$ & $\begin{array}{c}f_{c, \exp } \\
(\mathrm{MPa})\end{array}$ \\
\hline B110P125R1 & 2 & 40 & 110 & $12.5 \times 12.5$ & 60 & $12.5 \times 12.5$ & 5.12 & 56.30 & 30.47 \\
\hline B1 10P125R25 & 2 & 40 & 110 & $12.5 \times 12.5$ & 60 & $12.5 \times 12.5$ & 5.12 & 53.20 & 30.47 \\
\hline B1 10P125R4 & 2 & 40 & 110 & $12.5 \times 12.5$ & 60 & $12.5 \times 12.5$ & 5.12 & 43.90 & 30.47 \\
\hline B1 15P125R1 & 2 & 40 & 115 & $12.5 \times 12.5$ & 65 & $12.5 \times 25$ & 5.12 & 53.00 & 30.47 \\
\hline B1 15P125R25 & 2 & 40 & 115 & $12.5 \times 12.5$ & 65 & $12.5 \times 25$ & 5.12 & 49.30 & 30.47 \\
\hline B1 15P125R4 & 2 & 40 & 115 & $12.5 \times 12.5$ & 65 & $12.5 \times 25$ & 5.12 & 57.40 & 30.47 \\
\hline B120P125R1 & 2 & 40 & 120 & $12.5 \times 12.5$ & 70 & $12.5 \times 37.5$ & 4.267 & 55.70 & 30.47 \\
\hline B120P125R25 & 2 & 40 & 120 & $12.5 \times 12.5$ & 70 & $12.5 \times 37.5$ & 4.267 & 51.90 & 30.47 \\
\hline B120P125R4 & 2 & 40 & 120 & $12.5 \times 12.5$ & 70 & $12.5 \times 37.5$ & 4.267 & 55.20 & 30.47 \\
\hline B127P125R1 & 2 & 40 & 127 & $12.5 \times 12.5$ & 75 & $12.5 \times 50$ & 4.48 & 52.90 & 30.47 \\
\hline B127P125R25 & 2 & 40 & 127 & $12.5 \times 12.5$ & 75 & $12.5 \times 50$ & 4.48 & 49.60 & 30.47 \\
\hline B127P125R4 & 2 & 40 & 127 & $12.5 \times 12.5$ & 75 & $12.5 \times 50$ & 4.48 & 53.60 & 30.47 \\
\hline
\end{tabular}

Note: the pile caps were $15 \mathrm{~cm}$ wide.

\section{Table 9}

Properties of the pile caps analyzed by Mesquita [12]

\begin{tabular}{cccccccccc}
\hline $\begin{array}{c}\text { Tested } \\
\text { model }\end{array}$ & $\begin{array}{c}\text { Pile } \\
\text { number }\end{array}$ & $\begin{array}{c}\text { Height } \\
(\mathrm{cm})\end{array}$ & $\begin{array}{c}\text { Length } \\
(\mathrm{cm})\end{array}$ & $\begin{array}{c}\text { Pile section } \\
(\mathbf{c m} \times \mathrm{cm})\end{array}$ & $\begin{array}{c}\text { Distance } \\
\text { between } \\
\text { piles }(\mathrm{cm})\end{array}$ & $\begin{array}{c}\text { Column } \\
\text { section } \\
(\mathrm{cm} \times \mathrm{cm})\end{array}$ & $\begin{array}{c}\text { Column } \\
\text { reinforcement } \\
\text { rate }(\%)\end{array}$ & $\begin{array}{c}\theta\left({ }^{\circ}\right) \\
\mathrm{f}_{\mathrm{c} 23, \mathrm{exp}} \\
(\mathrm{MPa})\end{array}$ \\
\hline $\mathrm{M}$ & 2 & 30 & 100 & $20 \times 20$ & 50 & $20 \times 20$ & 8.043 & 56.31 & 42.21 \\
\hline Note: the pile caps were $50 \mathrm{~cm}$ wide; the fc23,exp value corresponds to the concrete strength at 23 days.
\end{tabular}


Table 10

Properties of the pile caps analyzed by Cao and Bloodworth [13]

\begin{tabular}{|c|c|c|c|c|c|c|c|c|c|}
\hline $\begin{array}{l}\text { Tested } \\
\text { model }\end{array}$ & $\begin{array}{c}\text { Pile } \\
\text { number }\end{array}$ & $\begin{array}{l}\text { Height } \\
(\mathrm{cm})\end{array}$ & $\begin{array}{l}\text { Length } \\
(\mathrm{cm})\end{array}$ & $\begin{array}{l}\text { Pile section } \\
(\mathrm{cm} \times \mathrm{cm})\end{array}$ & $\begin{array}{l}\text { Distance } \\
\text { between } \\
\text { piles }(\mathrm{cm})\end{array}$ & $\begin{array}{l}\text { Column } \\
\text { section } \\
(\mathrm{cm} \times \mathrm{cm})\end{array}$ & $\begin{array}{l}\text { Column } \\
\text { reinforcement } \\
\text { rate (\%) }\end{array}$ & $\theta\left({ }^{\circ}\right)$ & $\begin{array}{l}f_{c, \exp } \\
(\mathrm{MPa})\end{array}$ \\
\hline B4A1 & 4 & 23 & 110 & 13 & 80 & $20 \times 50$ & - & 24.98 & 20.30 \\
\hline B4A2 & 4 & 23 & 95 & 13 & 65 & $20 \times 50$ & - & 29.07 & 21.80 \\
\hline B4A3 & 4 & 23 & 85 & 13 & 55 & $20 \times 50$ & - & 32.43 & 24.30 \\
\hline B4A4 & 4 & 23 & 80 & 13 & 50 & $20 \times 50$ & - & 34.32 & 24.40 \\
\hline B4A5 & 4 & 23 & 70 & 13 & 40 & $20 \times 50$ & - & 38.52 & 23.00 \\
\hline B4B2 & 4 & 23 & 95 & 13 & 65 & $20 \times 65$ & - & 26.84 & 25.60 \\
\hline B4B3 & 4 & 23 & 95 & 13 & 65 & $20 \times 75$ & - & 25.16 & 24.70 \\
\hline
\end{tabular}

Note: the first 5 models were $50 \mathrm{~cm}$ wide, the others were $65 \mathrm{~cm}$ and $75 \mathrm{~cm}$ wide, respectively.

The upper nodal stress (contact stress between column/pile cap) is calculated by equation [4], while the nodal stress for the lower nodal zone (contact stress between pile cap/pile) are calculated by equations [5], [6] and [7] for caps on two, three and four piles, respectively.

$\sigma_{\mathrm{zns}}=\frac{\mathrm{F}_{\mathrm{u}, \exp }}{\mathrm{A}_{\mathrm{c}} \cdot \sin ^{2}(\theta)}$

$\sigma_{\mathrm{zni}}=\frac{\mathrm{F}_{\mathrm{u}, \exp }}{2 \cdot \mathrm{A}_{\mathrm{est}} \cdot \sin ^{2}(\theta)}$

$\sigma_{\mathrm{zni}}=\frac{\mathrm{F}_{\mathrm{u}, \exp }}{3 \cdot \mathrm{A}_{\mathrm{est}} \cdot \sin ^{2}(\theta)}$

$\sigma_{\mathrm{zni}}=\frac{\mathrm{F}_{\mathrm{u}, \exp }}{4 \cdot \mathrm{A}_{\mathrm{est}} \cdot \sin ^{2}(\theta)}$

in which:

$F_{u, \text { exp }}$, is the ultimate experimental force applied to the column;

$A_{c}$ is the column cross-sectional area;

$A_{\text {est }}$ is the pile cross-sectional area and;

$\theta$ is the strut angle of inclination.

Schlaich and Schäfer [14] proposed a more precise formulation, in which they consider the type of truss node. The authors differentiate existing nodes according to the acting stress and the presence or not of anchored bars. In this way, the upper nodal region is represented by Figure [4], node only subjected to compressive stresses, and the lower nodal region is represented by Figure [5], node where the bars are anchored, therefore, with incidence of tensile stresses.

The analysis of Figure [4] suggests that the upper node is subject-

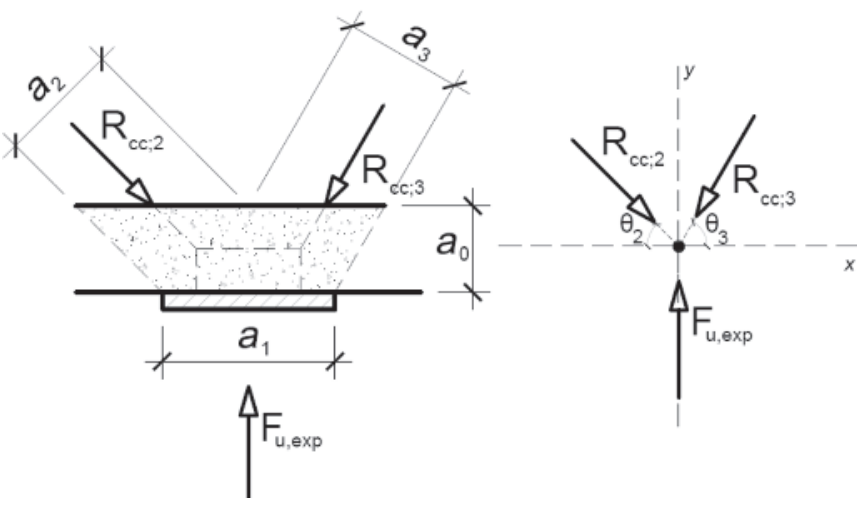

\section{Figure 4}

Node subjected only to compressive stresses, adapted according to Schlaich and Schäfer [14] ed to the triple stress state, since the volume of delimited concrete by $\mathrm{a}_{0}$ is subjected to compressive forces acting in different directions. According to Schlaich and Schäfer [14], it is convenient to choose the $\mathrm{a}_{0}$ value as presented by equation [8].

$a_{0} \geq a_{1} \cdot \cos \left(\theta_{2}\right) \cdot \sin \left(\theta_{2}\right)=a_{1} \cdot \cos \left(\theta_{3}\right) \cdot \sin \left(\theta_{3}\right)$

However, a limit value for $\mathrm{a}_{0}$ is not presented. The upper and lower nodal stresses calculation is done using equations [9] and [10] respectively.

$\sigma_{\mathrm{zns}}=\frac{\mathrm{F}_{\mathrm{u}, \exp }}{\mathrm{a}_{1} \cdot \mathrm{b}}$

$\sigma_{\mathrm{zni}}=\frac{\mathrm{R}_{\mathrm{est}} / \mathrm{A}_{\mathrm{est}}}{\left[1+\left(\frac{\mathrm{u} \cdot \operatorname{cotg}(\theta)}{\mathrm{a}_{1}}\right)\right] \cdot \sin ^{2}(\theta)}$

being that:

$F_{u, \text { exp }}$, is the ultimate experimental force applied to the column;

$\mathrm{R}_{\text {est }}$ is the reaction of $\mathrm{F}_{\mathrm{u}, \mathrm{exp}}$ on each pile;

$A_{\text {est }}$ is the pile cross-sectional area;

$a_{0}$ is the area of contribution near the upper nodal zone;

$a_{1}$ is the dimension of column or pile, measured in the direction of the strut;

$\mathrm{b}$ is the dimension of the column measured in a direction perpendicular to the strut;

$\mathrm{u}$ is the height in which longitudinal rebar is distributed considering a top concrete cover layer and;

$\theta$ is the strut angle of inclination.
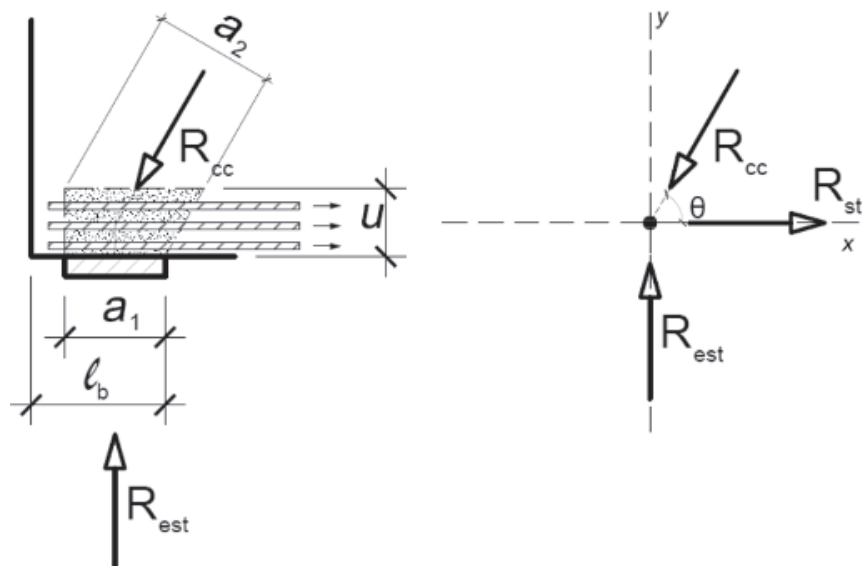

Figure 5

Node with anchored bars, adapted according to Schlaich and Schäfer [14] 


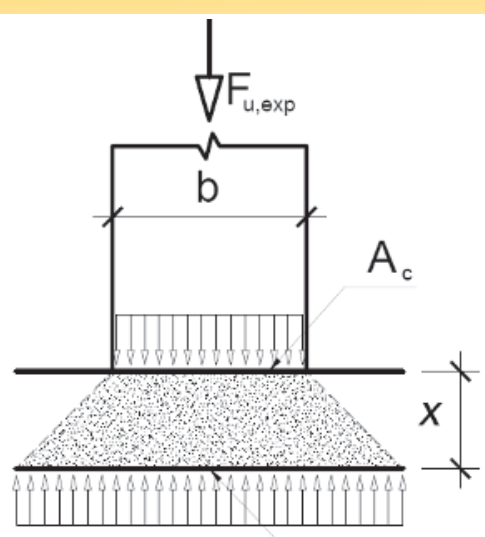

$A_{c, A m p}$

\section{Figure 6}

Extended area $\mathrm{A}_{\mathrm{c}, \mathrm{Amp}}$, adapted according to Fusco [15]

Unlike the other authors, Fusco [15] suggests that the column reinforcement rate affects the transmission of the compressive force from the colum to the pile cap.

As shown in Figure [6], Fusco [15] analyzes the compressive stress in an amplified concrete area $A_{c, A m p}$, at an $x$ value of distance from the top of the pile cap.

This enlarged area is approximately nine times larger than the column section area and its position depends only on the column's reinforcement rate. As shown in Table [21], the higher the reinforcement rate existing in the column, the furthest from the upper face is the area $A_{c, A m p}$. The value of $x$ is only indicative of the position of the enlarged area in relation to the upper face of the pile cap, since the position of $x$ does not interfere with the value of $A_{c, A m p}$.

Another important aspect is that Fusco [15] indicates that the stress in the lower nodal zone is within acceptable limits based on the stress acting on the pile. So, according to the model proposed by Fusco [15], it is possible to calculate the stresses in the upper nodal zones and lower with equations [11] and [12], respectively.

$\sigma_{\mathrm{zns}}=\frac{\sigma_{\mathrm{cv}, \mathrm{d}}}{\sin ^{2}(\theta)}$

$\sigma_{\mathrm{zni}}=\frac{\mathrm{R}_{\mathrm{est}}}{1,4 \cdot \mathrm{A}_{\mathrm{est}}}$

being that:

$\sigma_{c v ; d}$ is the vertical stress at the $x$ depth from the top of the cap, calculated by $\frac{\mathrm{F}_{\mathrm{u}, \exp }}{\mathrm{A}_{\mathrm{c}, \mathrm{Amp}}}$;

$\mathrm{F}_{\mathrm{u} \text { exp }}$ is the the ultimate load applied to the column;

$A_{c, \text { Amp }}$ is the cross-sectional area of the column pivoted at $x$ depth relative to the top of the pile cap;

$R_{\text {est }}$ is the reaction on the pile;

$A_{\text {est }}$ is the pile cross-sectional area and;

$\theta$ is the strut angle of inclination.

\subsection{Limits of nodal stress values}

As the purpose of this work is to compare the stresses calculation models with the limits indicated by the norms, the limits proposed by the authors Blévot and Frémy [2], Schlaich and Schäfer [14] and Fusco [15], as well as the norms ABNT NBR 6118:2014 [3], EHE-1998 [16], ACI 318-14 [17], CEB-fib [18] and CEB-fib [19] were considered.
As for the experimental data, the coefficient $\mathrm{Y}_{\mathrm{c}}$ that lowers the resistance of the concrete was not considered, as it is used only for design. In the same way, the Rüsch effect and the $\alpha_{\mathrm{v} 2}$ coefficient were not considered, since the forces applied in the models up to their failure were not of long duration.

Table [22] shows all the limits considered for the analysis according to the following types of nodes:

Node CCC - prismatics strut;

- Node CCT - struts crossed by a single tie and;

node CTT ou TTT - struts crossed by more than one tie. Considering that the concrete in the column/cap contact region subjected to a triple stress state, it is proposed by the authors of this work that the stress limit for the upper nodal zone is equal to the concrete strength on triple stress state proposed in ABNT NBR 6118:2014 [3]. If the concrete is subjected to the triple stress state, considering $\sigma_{3} \geq \sigma_{2} \geq \sigma_{1}$, the following limit is considered:

$\sigma_{3}=\mathrm{f}_{\mathrm{ck}}+4 \cdot \sigma_{1}$

being that: $\sigma_{1} \geq-f_{\text {ctk }}$ (being the tensile stress considered negative). In this way, the limit value for the stress in the upper nodal zone is a value higher than the proposed value (for CCC nodes) by ABNT NBR 6118:2014 [3].

Finally, the authors make an observation regarding the limits presented. The book ABNT NBR 6118: 2014 Comentários e Exemplos de Aplicação [20], edited by the Instituto Brasileiro do Concreto (IBRACON), is mistaken about the limits established by Blévot and Frémy [2]. In the publication it is said that the limits for nodal stresses, both upper and lower, depend on an a factor, and that such factor depends on the number of piles in which the pile cap is supported. The book considers that the $\alpha$ value is applied to both the upper nodal zone and the lower nodal zone.

According to Blévot and Frémy [2], the value of a should be applied only to the upper nodal zone, as shown in Table [22].

\section{Results and discussions}

For each pile cap tested from each of the mentioned authors, the ultimate experimental force and the angle of inclination of the struts were extracted. With this information, equations [1], [2] and [3] were applied to find reaction forces on piles, on the struts and on the ties that acted on the models. The results of this calculation step are shown in Tables [11] to [20].

Thus, with such forces, it is possible to apply the models for calculating the nodal stresses and compare with each of the limits presented by Table [22].

Looking closely at Table [22] it is noted that, after excluding the safety coefficients, many limits became equal. Thus, it can be verified that one of the factors that cause the discrepancy between the limits are the safety coefficients that each norm and authors adopt. The obtained results for the operating stresses and limit stresses for the last test situation for both the upper nodal zone $\left(\sigma_{\mathrm{zns}}\right)$ and the lower nodal zone $\left(\sigma_{z n i}\right)$ of each author, according to the presented equations, are shown in Tables [23] to [33].

In order to facilitate the understanding, the graphs of Figures [7] to [26] show, for each author, on the x-axis the tested model and on the $y$-axis the values of the stresses calculated by each of the aforementioned methods. The horizontal lines represent the mean values of the limiting stresses in $\mathrm{kN} / \mathrm{cm}^{2}$. Figures [27] and [28] show all models in a single graph.

The analysis of the graphs confirms the discrepancy between the limits, however, the boundaries for the lower nodal zone are closer than the upper nodal zone limits for all pile caps.

For the caps tested by Mautoni [5], it is observed that the limits 
established by Schlaich and Schäfer [14] and CEB-fib [19] for the lower nodal zone show values closer to the mean value, whereas for the upper nodal zone, the stresses are better represented by both the Schlaich and Schäfer limits [19] and by the limits of CEBfib [19] and ACI 318-14 [17].

The same reasoning can be expanded to the other cases, except for the caps tested by Adebar et al. [4]. The fact of laying the piles in different distances in $\mathrm{x}$ and $\mathrm{y}$, generated considerable variations in the calculated stresses.

The consideration of the multiaxial state of stresses was shown to be coherent in all cases, being the calculated value close to the value established by Schlaich and Schäfer [14].

In some particular cases, such as Chan and Poh [7] and Mesquita [12], the stresses for the lower nodal zone calculated by the Fusco [15]

Table 11

Forces acting in the tests performed by Mautoni [5]

\begin{tabular}{cccccc}
\hline Tested model & $\mathbf{F}_{\mathrm{r}}(\mathbf{k N})$ & $\mathbf{F}_{\mathrm{u}, \exp }(\mathbf{k N})$ & $\mathbf{R}_{\text {est }}(\mathbf{k N})$ & $\mathbf{R}_{\mathrm{cc}}(\mathbf{k N})$ & $\mathbf{R}_{\mathrm{st}}(\mathbf{k N})$ \\
\hline B1-1 & 368,669 & 508,165 & 254,083 & 306,394 & 171,230 \\
B2-1 & 318,849 & 508,165 & 254,083 & 306,394 & 171,230 \\
B1-2 & 199,280 & 348,741 & 174,371 & 212,412 & 121,301 \\
B2-2 & 199,280 & 348,741 & 174,371 & 212,412 & 121,301 \\
B1-A & 348,741 & 474,301 & 237,151 & 288,889 & 164,974 \\
B2-A & 348,741 & 747,301 & 373,651 & 455,169 & 259,931 \\
B1-B & 348,741 & 727,373 & 363,687 & 465,746 & 290,949 \\
B2-B & 318,849 & 727,373 & 363,687 & 465,746 & 290,949 \\
B1-4A & 298,920 & 667,589 & 333,795 & 427,466 & 267,036 \\
B2-4A & 318,849 & 667,589 & 333,795 & 427,466 & 267,036 \\
B1-4B & 308,884 & 627,733 & 313,867 & 401,945 & 251,093 \\
B2-4B & 318,849 & 627,733 & 313,867 & 401,945 & 251,093 \\
B1-4C & 249,100 & 498,201 & 249,101 & 319,004 & 199,280 \\
B2-4C & 298,920 & 498,201 & 249,101 & 319,004 & 199,280 \\
D1 & 229,172 & 508,165 & 254,083 & 330,741 & 211,735 \\
D2 & 229,172 & 508,165 & 254,083 & 330,741 & 211,735 \\
F1 & 229,172 & 478,723 & 239,362 & 338,508 & 239,362 \\
F2 & 209,244 & 478,273 & 239,137 & 338,190 & 239,137 \\
E1 & 169,388 & 368,669 & 184,335 & 277,460 & 207,376 \\
G1 & 199,280 & 458,345 & 229,173 & 344,950 & 257,819 \\
\hline
\end{tabular}

Table 12

Forces acting in the tests performed by Fusco [6]

\begin{tabular}{cccccc}
\hline Tested model & $\mathbf{F}_{\mathrm{r} .}(\mathrm{kN})$ & $\mathbf{F}_{\mathrm{u} \text { exp }}(\mathrm{kN})$ & $\mathbf{R}_{\text {est }}(\mathrm{kN})$ & $\mathbf{R}_{\mathrm{cc}}(\mathrm{kN})$ & $\mathbf{R}_{\mathrm{st}}(\mathrm{kN})$ \\
\hline A-1 & - & 393.000 & 196.500 & 264.417 & 176.929 \\
B-1 & 150.000 & 400.000 & 200.000 & 269.127 & 180.081 \\
C-1 & 150.000 & 400.000 & 200.000 & 269.127 & 180.081 \\
\hline
\end{tabular}

\section{Table 13}

Forces acting in the tests performed by Adebar et al. [4]

\begin{tabular}{|c|c|c|c|c|c|c|c|c|}
\hline $\begin{array}{l}\text { Tested } \\
\text { model }\end{array}$ & $F_{r .}(k N)$ & $F_{u, \exp }(k N)$ & $R_{\text {est; } x}(k N)$ & $\mathrm{R}_{\text {estiy }}(\mathrm{kN})$ & $R_{c c ; x}(k N)$ & $\mathbf{R}_{\mathrm{cc} ; \mathrm{y}}(\mathrm{kN})$ & $R_{\text {st; } x}(k N)$ & $R_{\text {st:y }}(k N)$ \\
\hline$A$ & - & $1,781.000$ & 445.250 & 445.250 & 730.264 & 556.563 & 578.825 & 333.938 \\
\hline B & - & $2,189.000$ & 547.250 & 547.250 & 897.557 & 684.063 & 711.425 & 410.438 \\
\hline C & - & $2,892.000$ & 723.000 & 723.000 & $1,411.702$ & $1,411.702$ & $1,212.507$ & $1,212.507$ \\
\hline D & - & $3,222.000$ & 805.500 & 805.500 & $1,321.118$ & $1,006.875$ & $1,407.150$ & 604.125 \\
\hline E & - & $4,709.000$ & $1,177.250$ & $1,177.250$ & $1,930.833$ & $1,471.563$ & $1,530.425$ & 882.938 \\
\hline $\mathrm{F}$ & - & $3,026.000$ & 756.500 & 756.500 & $1,240.752$ & 945.625 & 983.450 & 567.375 \\
\hline
\end{tabular}

\section{Table 14}

Forces acting in the tests performed by Chan and Poh [7]

\begin{tabular}{cccccc}
\hline Tested model & $\mathbf{F}_{\mathrm{r} .}(\mathbf{k N})$ & $\mathbf{F}_{\mathrm{u}, \text { exp }}(\mathbf{k N})$ & $\mathbf{R}_{\text {est }}(\mathbf{k N})$ & $\mathbf{R}_{\mathrm{cc}}(\mathbf{k N})$ & $\mathbf{R}_{\mathrm{st}}(\mathbf{k N})$ \\
\hline $\mathrm{A}$ & 840.000 & 1.230 .000 & 307.500 & 448.286 & 326.197 \\
$\mathrm{~B}$ & 900.000 & 1.250 .000 & 312.500 & 455.576 & 331.501 \\
$\mathrm{C}$ & 450.000 & 870.000 & 217.500 & 376.762 & 307.641 \\
\hline
\end{tabular}


Analysis of the nodal stresses in pile caps

\section{Table 15}

Forces acting in the tests performed by Miguel [8]

\begin{tabular}{|c|c|c|c|c|c|}
\hline Tested model & $F_{\mathrm{r} .}(\mathrm{kN})$ & $F_{u, \exp }(k N)$ & $R_{\text {est }}(k N)$ & $R_{c c}(k N)$ & $R_{\text {st }}(\mathrm{kN})$ \\
\hline B20A1/1 & $1,050.000$ & $1,512.000$ & 504.000 & 639.858 & 393.768 \\
\hline B20A1/2 & 900.000 & $1,648.000$ & 549.334 & 697.114 & 429.186 \\
\hline B20A2 & $1,050.000$ & $2,083.000$ & 694.334 & 881.122 & 542.473 \\
\hline B20A3 & $1,050.000$ & $1,945.000$ & 648.334 & 822.747 & 506.534 \\
\hline B2OA4 & $1,200.000$ & 2.375 .000 & 791.667 & $1,004.639$ & 618.518 \\
\hline B30A1 & 900.000 & $1,909.000$ & 636.334 & 807.519 & 497.158 \\
\hline B30A2 & $1,050.000$ & $2,674.000$ & 891.334 & $1,131.118$ & 696.386 \\
\hline B30A3 & 750.000 & $1,938.000$ & 646.000 & 819.786 & 504.711 \\
\hline B30A4 & 900.000 & $2,283.000$ & 761.000 & 965.723 & 594.558 \\
\hline
\end{tabular}

\section{Table 16}

Forces acting in the tests performed by Delalibera and Giongo [9]

\begin{tabular}{|c|c|c|c|c|c|}
\hline Tested model & $F_{\text {r. }}(k N)$ & $F_{u, \exp }(k N)$ & $R_{\text {est }}(k N)$ & $R_{c c}(k N)$ & $R_{\text {st }}(k N)$ \\
\hline B35P25E25 and 0 & 465.000 & $1,821.000$ & 910.500 & $1,287.641$ & 910.500 \\
\hline B35P25E25 and 2.5 & 445.000 & $1,688.000$ & 844.000 & $1,193.596$ & 844.000 \\
\hline B35P25E25 and $\mathrm{OA}_{\mathrm{swC}}$ & 270.000 & $1,880.000$ & 940.000 & $1,329.361$ & 940.000 \\
\hline B35P25E25 and OA ${ }_{\text {swo }}$ & 266.000 & $1,406.000$ & 703.000 & 994.192 & 703.000 \\
\hline B35P25E25 and OCG & 315.000 & $1,263.000$ & 631.500 & 893.076 & 631.500 \\
\hline B45P25E25 and 0 & 465.000 & $2,276.000$ & $1,138.000$ & $1,397.836$ & 811.728 \\
\hline B45P25E25 and 5 & 522.000 & $1,972.000$ & 986.000 & $1,211.130$ & 703.307 \\
\hline B45P25E25 and $\mathrm{OA}_{\mathrm{swc}}$ & 482.000 & $3,055.000$ & $1,527.500$ & $1,879.269$ & $1,089.555$ \\
\hline B45P25E25 and OA swo & 305.000 & $2,090.000$ & $1,045.000$ & $1,283.602$ & 745.391 \\
\hline B45P25E25 and OCG & 473.000 & $2,270.000$ & $1,135.000$ & $1,394.151$ & 809.588 \\
\hline B35P50E25 and 0 & 450.000 & $3,877.000$ & $1,938.500$ & $2,424.081$ & $1,455.467$ \\
\hline B35P50E25 and 12.5 & 585.000 & $3,202.000$ & $1,601.000$ & $2,002.039$ & $1,202.065$ \\
\hline B45P50E25 and 0 & 851.000 & $4,175.000$ & $2,087.500$ & $2,368.651$ & $1,119.308$ \\
\hline B45P50E25 and 12.5 & 477.000 & $3,386.000$ & $1,693.000$ & $1,921.018$ & 907.779 \\
\hline
\end{tabular}

Table 17

Forces acting in the tests performed by Barros [10]

\begin{tabular}{cccccc}
\hline Tested model & $\mathbf{F}_{\mathrm{r} .}(\mathbf{k N})$ & $\mathbf{F}_{\mathrm{u}, \exp }(\mathbf{k N})$ & $\mathbf{R}_{\text {est }}(\mathbf{k N})$ & $\mathbf{R}_{\mathrm{cc}}(\mathrm{kN})$ & $\mathbf{R}_{\text {st }}(\mathbf{k N})$ \\
\hline SR/M1 & 210.000 & 756.750 & 378.000 & 409.739 & 158.121 \\
CR/M8 & 200.000 & 725.000 & 362.500 & 395.285 & 157.619 \\
\hline
\end{tabular}

Table 18

Forces acting in the tests performed by Munhoz [11]

\begin{tabular}{cccccc}
\hline Tested model & $\mathbf{F}_{\mathrm{r} .}(\mathbf{k N})$ & $\mathbf{F}_{\mathrm{u}, \text { exp }}(\mathbf{k N})$ & $\mathbf{R}_{\text {est }}(\mathbf{k N})$ & $\mathbf{R}_{\mathrm{cc}}(\mathbf{k N})$ & $\mathbf{R}_{\mathrm{st}}(\mathbf{k N})$ \\
\hline B110P125R1 & 225.000 & 431.110 & 215.555 & 259.095 & 143.757 \\
B1 10P125R25 & 198.000 & 577.080 & 288.540 & 360.346 & 215.855 \\
B110P125R4 & 240.000 & 590.730 & 295.365 & 425.965 & 306.930 \\
B115P125R1 & 158.000 & 712.670 & 356.335 & 446.180 & 268.518 \\
B115P125R25 & 148.000 & 736.020 & 368.010 & 485.415 & 316.539 \\
B115P125R4 & 154.000 & 763.640 & 381.820 & 453.224 & 244.184 \\
B120P125R1 & 235.000 & 850.780 & 425.390 & 514.939 & 290.181 \\
B120P125R25 & 198.000 & 807.130 & 403.656 & 512.831 & 316.435 \\
B120P125R4 & 201.000 & 924.260 & 462.130 & 562.784 & 321.189 \\
B127P125R1 & 276.000 & 1.028 .300 & 514.150 & 644.634 & 388.849 \\
B127P125R25 & 247.000 & 979.880 & 489.940 & 643.356 & 416.972 \\
B127P125R4 & 185.000 & 969.350 & 484.675 & 602.160 & 357.333 \\
\hline
\end{tabular}

\section{Table 19}

Forces acting in the tests performed by Mesquita [12]

\begin{tabular}{cccccc}
\hline Tested model & $\mathbf{F}_{\mathrm{r} .}(\mathrm{kN})$ & $\mathbf{F}_{\mathrm{u} \text { exp }}(\mathrm{kN})$ & $\mathbf{R}_{\text {est }}(\mathrm{kN})$ & $\mathbf{R}_{\mathrm{cc}}(\mathrm{kN})$ & $\mathbf{R}_{\mathrm{st}}(\mathrm{kN})$ \\
\hline $\mathrm{M}$ & 600.000 & $2,150.000$ & $1,075.000$ & $1,291.988$ & 716.665 \\
\hline
\end{tabular}


Table 20

Forces acting in the tests performed by Cao and Bloodworth [13]

\begin{tabular}{cccccc}
\hline Tested model & $\mathbf{F}_{\mathrm{r.}}(\mathbf{k N})$ & $\mathbf{F}_{\mathrm{u}, \text { exp }}(\mathbf{k N})$ & $\mathbf{R}_{\text {est }}(\mathbf{k N})$ & $\mathbf{R}_{\mathrm{cc}}(\mathbf{k N})$ & $\mathbf{R}_{\text {st }}(\mathbf{k N})$ \\
\hline B4A1 & - & 592.000 & 148.000 & 350.497 & 317.717 \\
B4A2 & - & 548.000 & 137.000 & 281.947 & 246.425 \\
B4A3 & - & 919.000 & 229.750 & 428.460 & 361.653 \\
B4A4 & - & $1,052.000$ & 263.000 & 466.512 & 385.311 \\
B4A5 & - & $1,244.000$ & 311.000 & 499.370 & 390.703 \\
B4B2 & - & 713.000 & 178.250 & 394.825 & 352.297 \\
B4B3 & - & 769.000 & 192.250 & 452.146 & 409.238 \\
\hline
\end{tabular}

model are far below the limit values, including the limit values stipulated by Fusco [15].

For the models tested by Delalibera and Giongo [9] whose name ends with $A_{s w, c}$, the acting stresses were slightly higher because these models were detailed with a reinforcement designed to absorb the stresses that cause cracking of the compression struts. There was also a variability in the stresses when an eccentricity in the applied force was considered, as can be observed in models ending with e0, e2,5, e5 and e12,5.

The values of stresses calculated by the three proposed methods were conflicting with each other. The fact that Fusco [15] considered the stress in the upper nodal zone calculated in an area $A_{c, A m p}$ made the values much smaller in relation to the other calculated values. This fact is reflected in the limits, the model of calculation of stresses proposed by Fusco [15] is compatible only with the limits established by himself, however, it is necessary to point out that it is not clear how the author found the proposed limits.

The stresses calculated by the method of Schlaich and Schäfer [14] are those that present better results, since the values do not show great variability, which did not occur with the values calculated by the Blévot and Frémy [2] model. The stresses calculated by Blévot and Frémy [2] are, in many cases, outside the presented limits.

\section{Conclusions}

Analyzing the presented formulations for the calculation of stresses and limit values, the discrepancy between each method is evident. Therefore, the same pile cap can be considered "verified" or not depending on the model used to analyze the stresses.

The mean limit values for the lower nodal zone are closer to the mean values for the upper nodal zone, showing that the greatest

\section{Table 21}

$\mathrm{x} / \mathrm{b}$ values according to Fusco [15]

\begin{tabular}{cccc}
\hline $\begin{array}{c}\text { Column reinforcement rate } \\
\text { (\%) }\end{array}$ & $\mathbf{1 \%}$ & $\mathbf{2 \%}$ & $\mathbf{3 \%}$ \\
\hline Square columns & 0.8 & 1.0 & 1.2 \\
Very wide columns & 0.35 & 0.42 & 1.0 \\
\hline Note: b is the smallest plan dimension of the column. & &
\end{tabular}

discrepancy between the limits lies in the upper nodal zone.

Consideration of the multiaxial stress state of the concrete leads to intermediate values in relation to the values presented by Blévot and Frémy [2] and by Schlaich and Schäfer [14], which are higher than those indicated by ABNT NBR 6118:2014 [3], with the limit value that considers the multiaxial stress state being more representative when compared to the ultimate stress of the upper nodal zone.

The model presented by Fusco [15] discusses considerations regarding the upper nodal area that are not very clear, since there is no precise demonstration for the limit value of $2 / 9 f_{\mathrm{c}}$. The consideration of an amplified area $A_{c, A m p}$, distant $x$ from the upper face of the pile cap, causes the stresses to be very different when compared with the other methods. The stresses calculated by the Fusco [15] method are compatible only with the limit values presented by himself, therefore, the limits described by ABNT NBR 6118:2014 [3] cannot be applied when the stresses are calculated using the Fusco [15] model.

The limit given by the Spanish standard EHE-1998 [16] for the upper nodal zone is much higher than the other limits, as well as much higher than the value of the calculated stresses, so caution is recommended when considering it, because the analyzed pile caps failed with values of stress in the upper nodal zone

\section{Table 22}

FLimit values of stress for nodal regions without considering $\gamma_{\mathrm{c}^{\prime}}$ the Rüsch effect and $\alpha_{\mathrm{v} 2}$

\begin{tabular}{|c|c|c|c|}
\hline Criteria & CCC & ССт & CTT or TTT \\
\hline Blévot and Frémy [2] & \multicolumn{3}{|c|}{$\begin{array}{c}1.40 \mathrm{f}_{\mathrm{c}^{\prime}} \text { upper nodal area (for pile caps on two piles) } \\
1.75 \mathrm{f}_{\mathrm{c}} \text {, upper nodal area (for pile caps on three piles) } \\
2.10 \mathrm{f}_{\mathrm{c}^{\prime}} \text {; upper nodal area (for pile caps on four piles) } \\
\mathrm{f}_{\mathrm{c}^{\prime}} \text { lower nodal zone (for pile caps in any situation) }\end{array}$} \\
\hline Schlaich and Schäfer [14] & $1.10 f_{c}$ & $0.80 f_{c}$ & $0.80 f_{c}$ \\
\hline Fusco $[15]$ & $2 / 9 f_{c}$ & $0.50 f_{c}$ & $0.50 f_{c}$ \\
\hline ABNT NBR $6118: 2014$ [2] & $0.85 f_{c}$ & $0.72 f_{c}$ & $0.60 \mathrm{ff}_{\mathrm{c}}$ \\
\hline EHE-1998 [16] & $3.00 f_{c}$ & $0.70 f_{c}$ & $0.70 f_{c}$ \\
\hline $\mathrm{ACl}-2014[17]$ & $0.85 f_{c}$ & $0.68 f_{c}$ & $0.51 f_{c}$ \\
\hline CEB-fib [18] & $0.85 f_{c}$ & $0.60 f_{c}$ & $0.60 f_{c}$ \\
\hline CEB-fib [19] & $1.00 f_{c}$ & $0.75 f_{c}$ & $0.75 f_{c}$ \\
\hline Triple stress state & $\mathrm{f}_{\mathrm{ck}}+4 \mathrm{f}_{\mathrm{ctk}}$ & - & - \\
\hline
\end{tabular}


Table 23

Active stresses $\times$ Limits considered for Mautoni's [5] tests

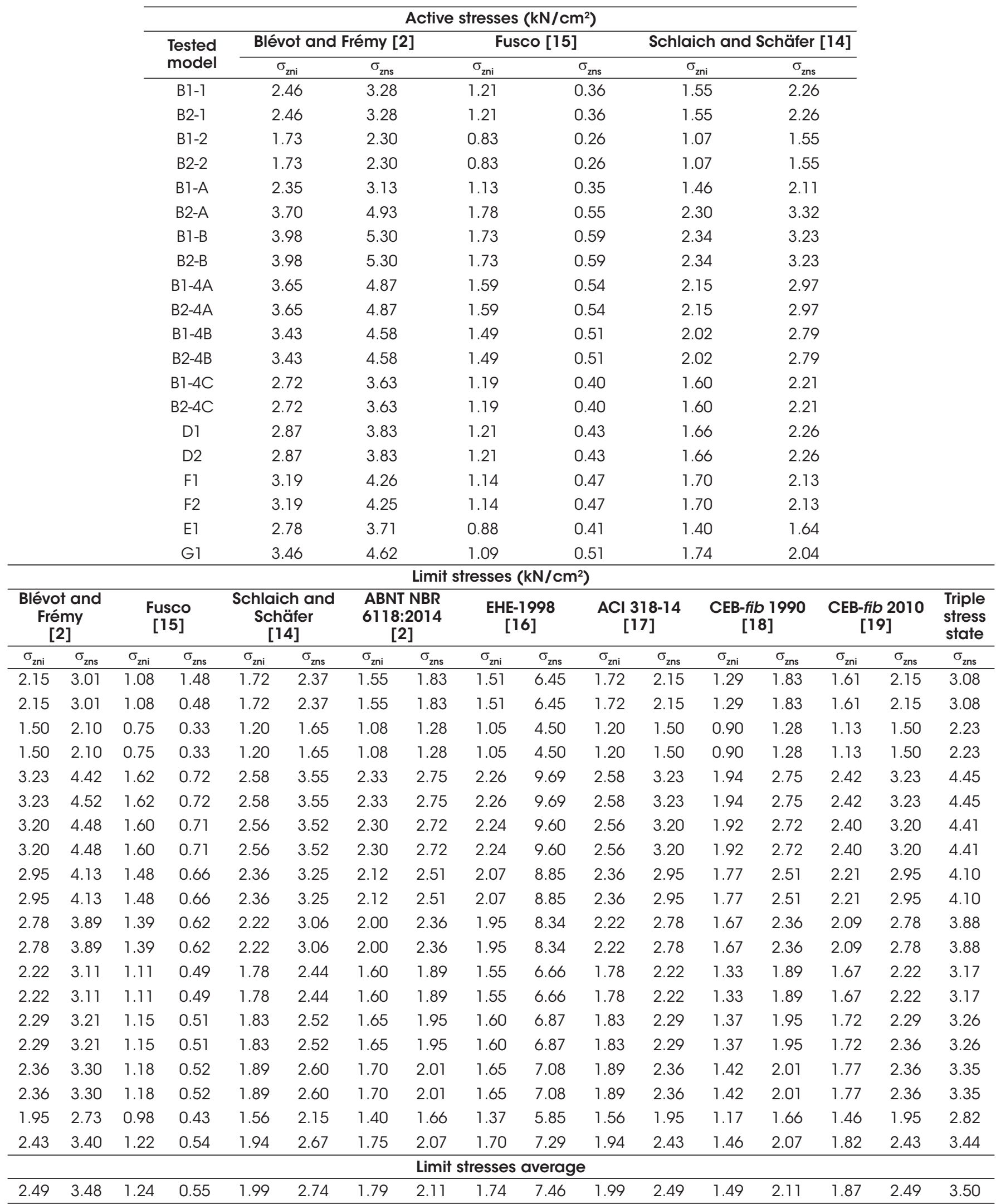


Table 24

Active stresses $\times$ Limits considered for Fusco's [6] tests

\begin{tabular}{ccccccc}
\hline \multicolumn{7}{c}{ Active stresses $\left(\mathrm{kN} / \mathrm{cm}^{2}\right)$} \\
\hline Tested & \multicolumn{7}{c}{ Blévot and Frémy [2] } & \multicolumn{2}{c}{ Fusco [15] } & \multicolumn{2}{c}{ Schlaich and Schäfer [14] } \\
\cline { 2 - 7 } model & $\sigma_{\mathrm{zni}}$ & $\sigma_{\mathrm{zns}}$ & $\sigma_{\mathrm{zni}}$ & $\sigma_{\mathrm{zns}}$ & $\sigma_{\mathrm{zni}}$ & $\sigma_{\mathrm{zns}}$ \\
\hline A-1 & 3.56 & 1.78 & 1.40 & 0.20 & 2.89 & 0.98 \\
B-1 & 3.62 & 1.81 & 1.43 & 0.20 & 2.95 & 1.00 \\
C-1 & 3.62 & 1.81 & 1.43 & 0.20 & 2.95 & 1.00
\end{tabular}

\begin{tabular}{|c|c|c|c|c|c|c|c|c|c|c|c|c|c|c|c|c|}
\hline \multicolumn{17}{|c|}{ Limit stresses $\left(\mathrm{kN} / \mathrm{cm}^{2}\right)$} \\
\hline \multicolumn{2}{|c|}{$\begin{array}{l}\text { Blévot and } \\
\text { Frémy } \\
\text { [2] }\end{array}$} & \multicolumn{2}{|c|}{$\begin{array}{c}\text { Fusco } \\
{[15]}\end{array}$} & \multicolumn{2}{|c|}{$\begin{array}{l}\text { Schlaich and } \\
\text { Schäfer } \\
\text { [14] }\end{array}$} & \multicolumn{2}{|c|}{$\begin{array}{c}\text { ABNT NBR } \\
6118: 2014 \\
\text { [2] }\end{array}$} & \multicolumn{2}{|c|}{$\begin{array}{c}\text { EHE-1998 } \\
{[16]}\end{array}$} & \multicolumn{2}{|c|}{$\begin{array}{c}\mathrm{ACl} 318-14 \\
{[17]}\end{array}$} & \multicolumn{2}{|c|}{$\begin{array}{c}\text { CEB-fib } 1990 \\
{[18]}\end{array}$} & \multicolumn{2}{|c|}{$\begin{array}{c}\text { CEB-fib } 2010 \\
{[19]}\end{array}$} & \multirow{2}{*}{$\begin{array}{c}\begin{array}{c}\text { Triple } \\
\text { stress } \\
\text { state }\end{array} \\
\sigma_{\text {zns }} \\
\end{array}$} \\
\hline$\sigma_{\mathrm{zni}}$ & $\sigma_{\mathrm{zns}}$ & $\sigma_{\mathrm{zni}}$ & $\sigma_{\text {zns }}$ & $\sigma_{\mathrm{zni}}$ & $\sigma_{\mathrm{zns}}$ & $\sigma_{\mathrm{zni}}$ & $\sigma_{\mathrm{zns}}$ & $\sigma_{\mathrm{zni}}$ & $\sigma_{\mathrm{zns}}$ & $\sigma_{\mathrm{zni}}$ & $\sigma_{\text {zns }}$ & $\sigma_{\mathrm{zni}}$ & $\sigma_{\text {zns }}$ & $\sigma_{\mathrm{zni}}$ & $\sigma_{\mathrm{zns}}$ & \\
\hline 2.72 & 3.81 & 1.36 & 0.60 & 2.18 & 2.99 & 1.96 & 2.31 & 1.90 & 8.16 & 2.18 & 2.72 & 1.63 & 2.31 & 2.04 & 2.72 & 3.81 \\
\hline 2.39 & 3.35 & 1.20 & 0.53 & 1.91 & 2.63 & 1.72 & 2.03 & 1.67 & 7.17 & 1.91 & 2.39 & 1.43 & 2.03 & 1.79 & 2.39 & 3.39 \\
\hline 2.39 & 3.35 & 1.20 & 0.53 & 1.91 & 2.63 & 1.72 & 2.03 & 1.67 & 7.17 & 1.91 & 2.39 & 1.43 & 2.03 & 1.79 & 2.39 & 3.39 \\
\hline \multicolumn{17}{|c|}{ Limit stresses average } \\
\hline 2.50 & 3.50 & 1.25 & 0.56 & 2.00 & 2.75 & 1.80 & 2.13 & 1.75 & 7.50 & 2.00 & 2.50 & 1.50 & 2.13 & 1.88 & 2.50 & 3.53 \\
\hline
\end{tabular}

Table 25

Active stresses in $x$ direction $x$ Limits considered for Adebar et al. [4] tests

\begin{tabular}{|c|c|c|c|c|c|c|}
\hline \multicolumn{7}{|c|}{ Active stresses $\left(\mathrm{kN} / \mathrm{cm}^{2}\right)$} \\
\hline \multirow{2}{*}{$\begin{array}{l}\text { Tested } \\
\text { model }\end{array}$} & \multicolumn{2}{|c|}{ Blévot and Frémy [2] } & \multicolumn{2}{|c|}{ Fusco $[15]$} & \multicolumn{2}{|c|}{ Schlaich and Schäfer [14] } \\
\hline & $\sigma_{\mathrm{zni}}$ & $\sigma_{\mathrm{zns}}$ & $\sigma_{\mathrm{zni}}$ & $\sigma_{\mathrm{zns}}$ & $\sigma_{\mathrm{zni}}$ & $\sigma_{\mathrm{zns}}$ \\
\hline$A_{x}$ & 3.81 & 5.32 & 1.01 & 0.59 & 3.81 & 1.98 \\
\hline$B_{x}$ & 4.69 & 6.54 & 1.24 & 0.73 & 2.37 & 2.43 \\
\hline$C_{x}$ & 8.77 & 12.25 & 1.64 & 1.36 & 7.51 & 3.21 \\
\hline$D_{x}$ & 6.90 & 9.63 & 1.83 & 1.07 & 3.49 & 3.58 \\
\hline$E_{x}$ & 10.08 & 14.07 & 2.68 & 1.56 & 8.92 & 5.23 \\
\hline$F_{x}$ & 6.48 & 9.04 & 1.72 & 1.00 & 3.28 & 3.36 \\
\hline
\end{tabular}

\begin{tabular}{|c|c|c|c|c|c|c|c|c|c|c|c|c|c|c|c|c|}
\hline \multicolumn{2}{|c|}{$\begin{array}{l}\text { Blévot and } \\
\text { Frémy } \\
\text { [2] }\end{array}$} & \multicolumn{2}{|c|}{$\begin{array}{c}\text { Fusco } \\
{[15]}\end{array}$} & \multicolumn{2}{|c|}{$\begin{array}{c}\text { Schlaich and } \\
\text { Schäfer } \\
\text { [14] }\end{array}$} & \multicolumn{2}{|c|}{$\begin{array}{c}\text { ABNT NBR } \\
6118: 2014 \\
{[2]}\end{array}$} & \multicolumn{2}{|c|}{$\begin{array}{c}\text { EHE-1998 } \\
{[16]}\end{array}$} & \multicolumn{2}{|c|}{$\begin{array}{c}\mathrm{ACl} 318-14 \\
{[17]}\end{array}$} & \multicolumn{2}{|c|}{$\begin{array}{c}\text { CEB-fib } 1990 \\
{[18]}\end{array}$} & \multicolumn{2}{|c|}{$\begin{array}{c}\text { CEB-fib } 2010 \\
\text { [19] }\end{array}$} & \multirow{2}{*}{$\begin{array}{c}\begin{array}{c}\text { Triple } \\
\text { stress } \\
\text { state }\end{array} \\
\sigma_{\text {zns }} \\
\end{array}$} \\
\hline$\sigma_{\mathrm{zni}}$ & $\sigma_{\mathrm{zns}}$ & $\sigma_{\mathrm{zni}}$ & $\sigma_{\text {zns }}$ & $\sigma_{\mathrm{zni}}$ & $\sigma_{\mathrm{zns}}$ & $\sigma_{\mathrm{zni}}$ & $\sigma_{\mathrm{zns}}$ & $\sigma_{\text {zni }}$ & $\sigma_{\mathrm{zns}}$ & $\sigma_{\mathrm{zni}}$ & $\sigma_{\text {zns }}$ & $\sigma_{\mathrm{zni}}$ & $\sigma_{\mathrm{zns}}$ & $\sigma_{\mathrm{zni}}$ & $\sigma_{\text {zns }}$ & \\
\hline 2.48 & 5.21 & 1.24 & 0.55 & 1.98 & 2.73 & 1.49 & 2.11 & 1.74 & 7.44 & 1.49 & 2.48 & 1.49 & & 1.86 & & 3.50 \\
\hline 2.48 & 5.21 & 1.24 & & 1.98 & 2. & 1.49 & 2.11 & & & & & & & & & 3.50 \\
\hline 2.71 & 5.69 & 1.36 & 0.60 & 2.17 & 2.98 & 1.63 & 2.30 & 1.90 & & & & & & 2.03 & & 3.79 \\
\hline 3.03 & 6.36 & 1.52 & 0.67 & 2.42 & 3.33 & 1.82 & 2.58 & 2.12 & 9.09 & 1.82 & 3.03 & 1.82 & 2.58 & 2.27 & 3.03 & 4.20 \\
\hline 4.11 & 8.63 & 2.06 & 0.91 & 3.29 & 4.52 & 2.47 & 3.49 & 2.88 & 12.33 & 2.47 & 4.11 & 2.47 & 3.49 & 3.08 & 4.11 & 5.54 \\
\hline 3.03 & 6.36 & 1.52 & 0.67 & 2.42 & 3.33 & 1.82 & 2.58 & 2.12 & 9.09 & 1.82 & 3.03 & 1.82 & 2.58 & 2.27 & 3.03 & 4.20 \\
\hline \multicolumn{17}{|c|}{ Limit stresses average } \\
\hline 2.97 & 6.24 & 1.49 & 0.66 & 2.38 & 3.27 & 1.78 & 2.53 & 2.08 & 8.92 & 1.78 & 2.97 & 1.78 & 2.53 & 2.23 & 2.97 & 4.12 \\
\hline
\end{tabular}


Table 26

Active stresses in y direction $\times$ Limits considered for Adebar et al. [4]

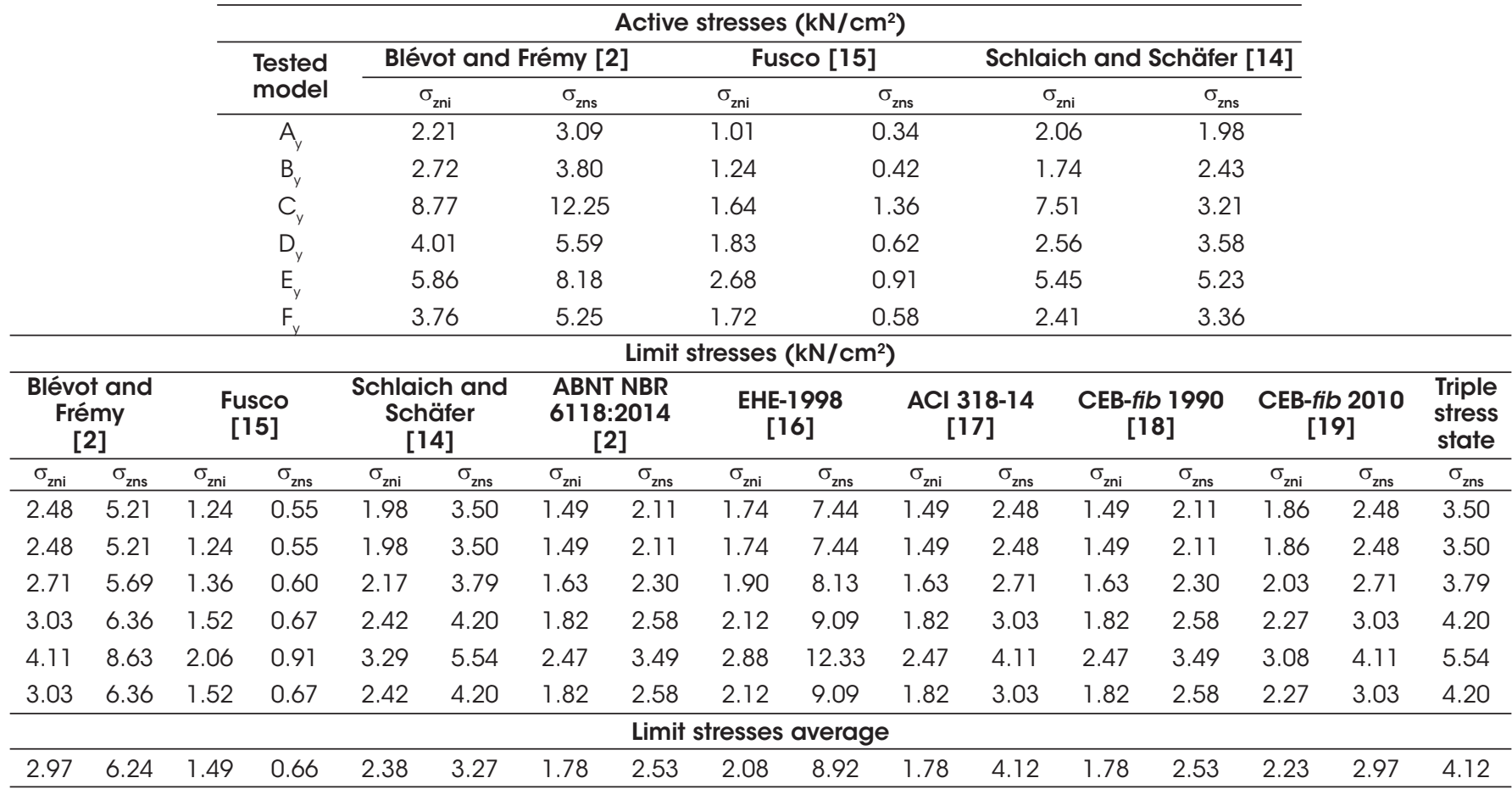

\section{Table 27}

Active stresses $\times$ Limits considered for Chan and Poh's [7] tests

\begin{tabular}{ccccccc}
\hline \multicolumn{7}{c}{ Active stresses (kN/cm $)^{2}$} \\
\hline \multirow{2}{*}{$\begin{array}{c}\text { Tested } \\
\text { model }\end{array}$} & \multicolumn{7}{c}{ Blévot and Frémy [2] } & \multicolumn{2}{c}{ Fusco [15] } & \multicolumn{2}{c}{ Schlaich and Schäfer [14] } \\
\cline { 2 - 7 } & $\sigma_{\mathrm{zni}}$ & $\sigma_{\mathrm{zns}}$ & $\sigma_{\mathrm{zni}}$ & $\sigma_{\mathrm{zns}}$ & $\sigma_{\mathrm{zni}}$ & $\sigma_{\mathrm{zns}}$ \\
\hline $\mathrm{A}$ & 2.90 & 6.54 & 0.98 & 0.73 & 2.53 & 3.08 \\
$\mathrm{~B}$ & 2.95 & 6.64 & 0.99 & 0.74 & 2.57 & 3.13 \\
$\mathrm{C}$ & 2.90 & 6.53 & 0.69 & 0.73 & 2.42 & 2.18
\end{tabular}

\begin{tabular}{|c|c|c|c|c|c|c|c|c|c|c|c|c|c|c|c|c|}
\hline \multicolumn{17}{|c|}{ Limit stresses $\left(\mathrm{kN} / \mathrm{cm}^{2}\right)$} \\
\hline \multicolumn{2}{|c|}{$\begin{array}{l}\text { Blévot and } \\
\text { Frémy } \\
\text { [2] }\end{array}$} & \multicolumn{2}{|c|}{$\begin{array}{l}\text { Fusco } \\
{[15]}\end{array}$} & \multicolumn{2}{|c|}{$\begin{array}{c}\text { Schlaich and } \\
\text { Schäfer } \\
\text { [14] }\end{array}$} & \multicolumn{2}{|c|}{$\begin{array}{c}\text { ABNT NBR } \\
6118: 2014 \\
{[2]} \\
\end{array}$} & \multicolumn{2}{|c|}{$\begin{array}{c}\text { EHE-1998 } \\
{[16]}\end{array}$} & \multicolumn{2}{|c|}{$\begin{array}{c}\mathrm{ACl} 318-14 \\
{[17]}\end{array}$} & \multicolumn{2}{|c|}{$\begin{array}{c}\text { CEB-fib } 1990 \\
{[18]}\end{array}$} & \multicolumn{2}{|c|}{$\begin{array}{c}\text { CEB-fib } 2010 \\
{[19]}\end{array}$} & \multirow{2}{*}{$\begin{array}{c}\begin{array}{c}\text { Triple } \\
\text { stress } \\
\text { state }\end{array} \\
\sigma_{\text {zns }} \\
\end{array}$} \\
\hline$\sigma_{\mathrm{zni}}$ & $\sigma_{\mathrm{zns}}$ & $\sigma_{\mathrm{zni}}$ & $\sigma_{\mathrm{zns}}$ & $\sigma_{\mathrm{zni}}$ & $\sigma_{\mathrm{zns}}$ & $\sigma_{\mathrm{zni}}$ & $\sigma_{\mathrm{zns}}$ & $\sigma_{\mathrm{zni}}$ & $\sigma_{\mathrm{zns}}$ & $\sigma_{\mathrm{zni}}$ & $\sigma_{\mathrm{zns}}$ & $\sigma_{\mathrm{zni}}$ & $\sigma_{\mathrm{zns}}$ & $\sigma_{\mathrm{zni}}$ & $\sigma_{\text {zns }}$ & \\
\hline 3.97 & 8.34 & 1.99 & 0.88 & 3.18 & 4.37 & 2.38 & 3.37 & 2.78 & 11.91 & 2.38 & 3.97 & 2.38 & 3.37 & 2.98 & 3.97 & 5.37 \\
\hline 3.83 & 8.04 & 1.92 & 0.85 & 3.06 & 4.21 & 2.30 & 3.26 & 2.68 & & 2.30 & 3.83 & 2.30 & 3.2 & 2.87 & 3.83 & 5.19 \\
\hline 3.64 & 7.64 & 1.82 & 0.81 & 2.91 & 4.00 & 2.18 & 3.09 & 2.55 & 10.92 & 2.18 & 3.64 & 2.18 & 3.09 & 2.73 & 3.65 & 4.96 \\
\hline \multicolumn{17}{|c|}{ Limit stresses average } \\
\hline 3.81 & 8.01 & 1.91 & 0.85 & 3.05 & 4.19 & 2.29 & 3.24 & 2.67 & 11.44 & 2.29 & 3.81 & 2.29 & 3.24 & 2.86 & 3.81 & 5.17 \\
\hline
\end{tabular}




\section{Table 28}

Active stresses $\times$ Limits considered for Miguel's [8] tests

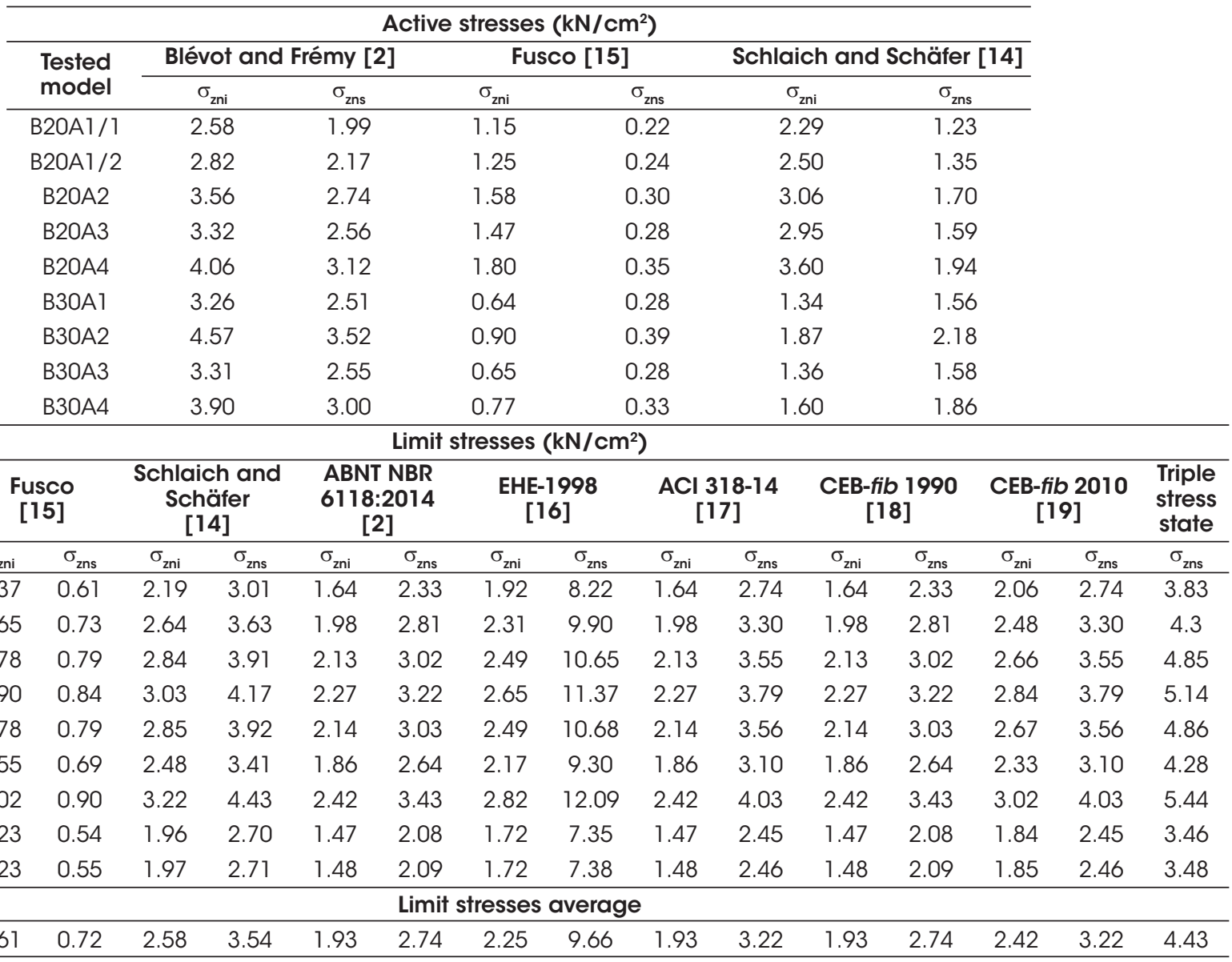


Table 29

Active stresses $\times$ Limits considered for Delalibera and Giongo's [9] tests

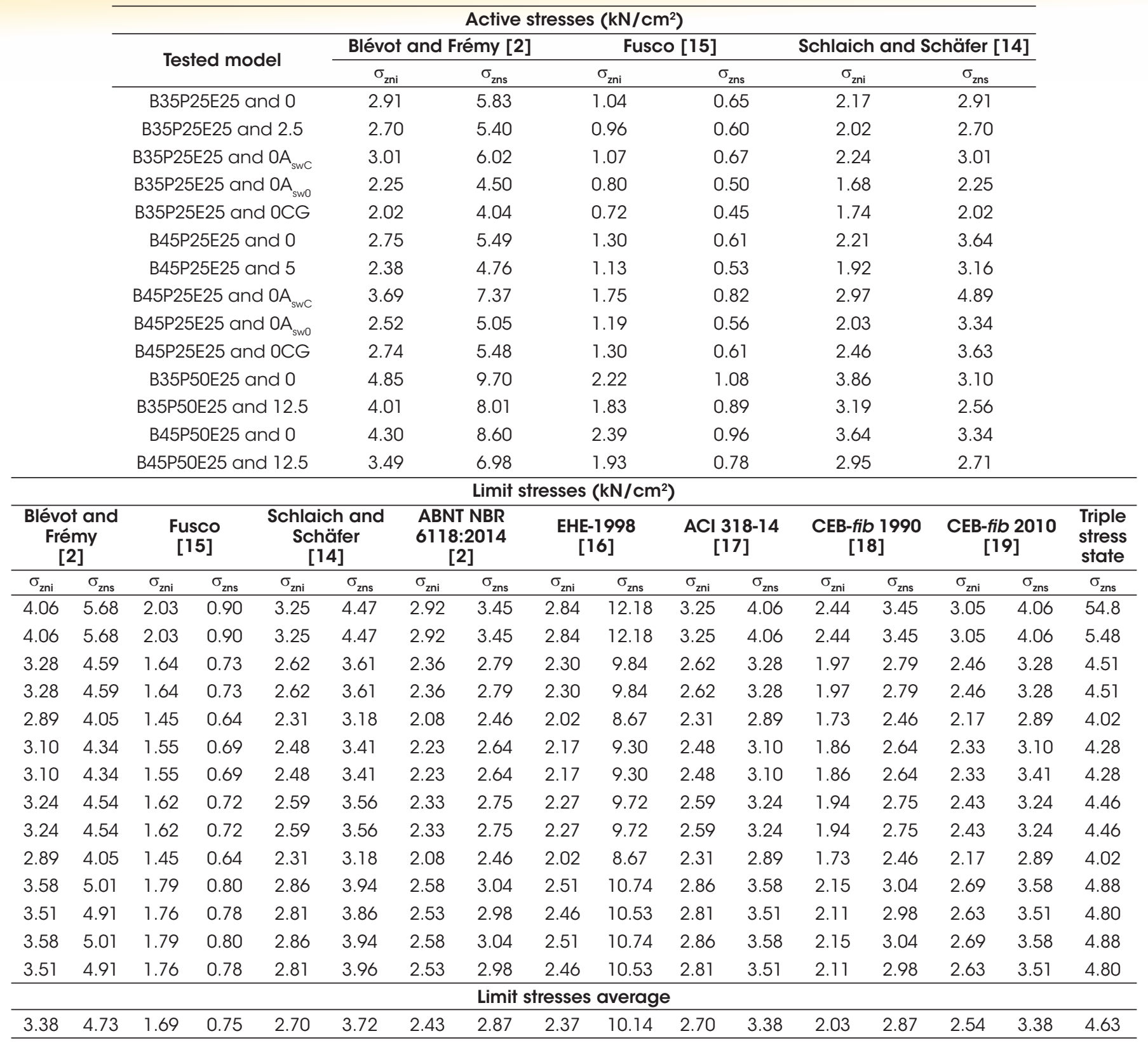

Table 30

Active stresses $\times$ Limits considered for Barros's [10] tests

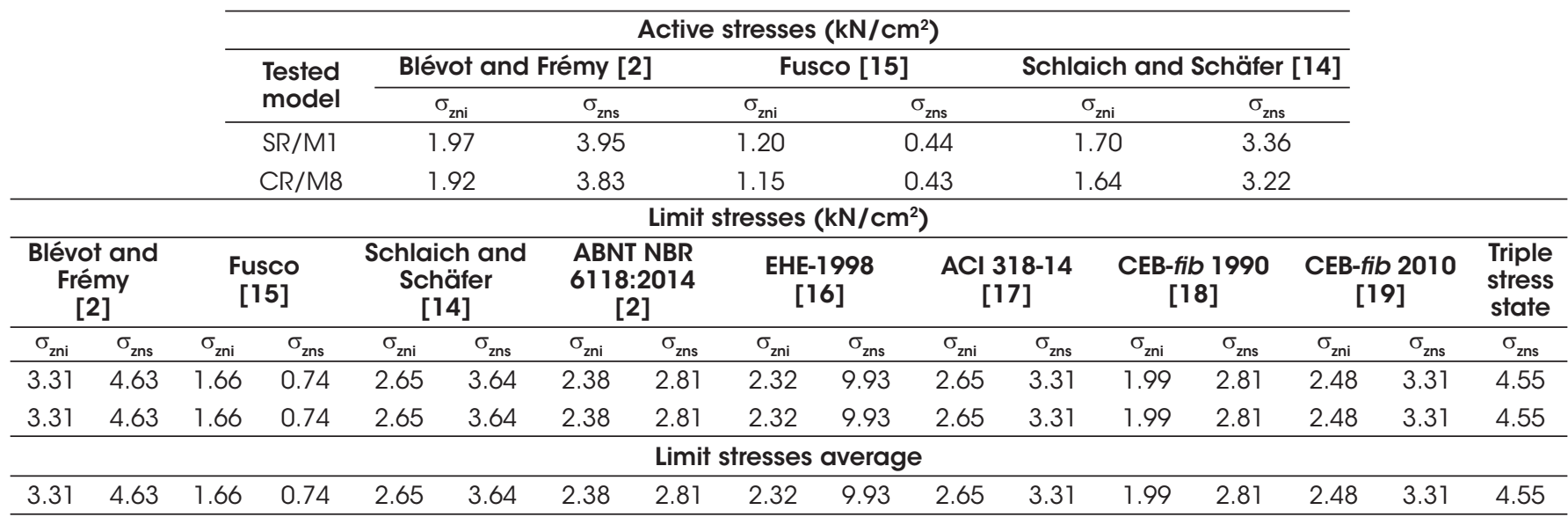




\section{Table 31}

Active stresses $\times$ Limits considered for Munhoz's [11] tests

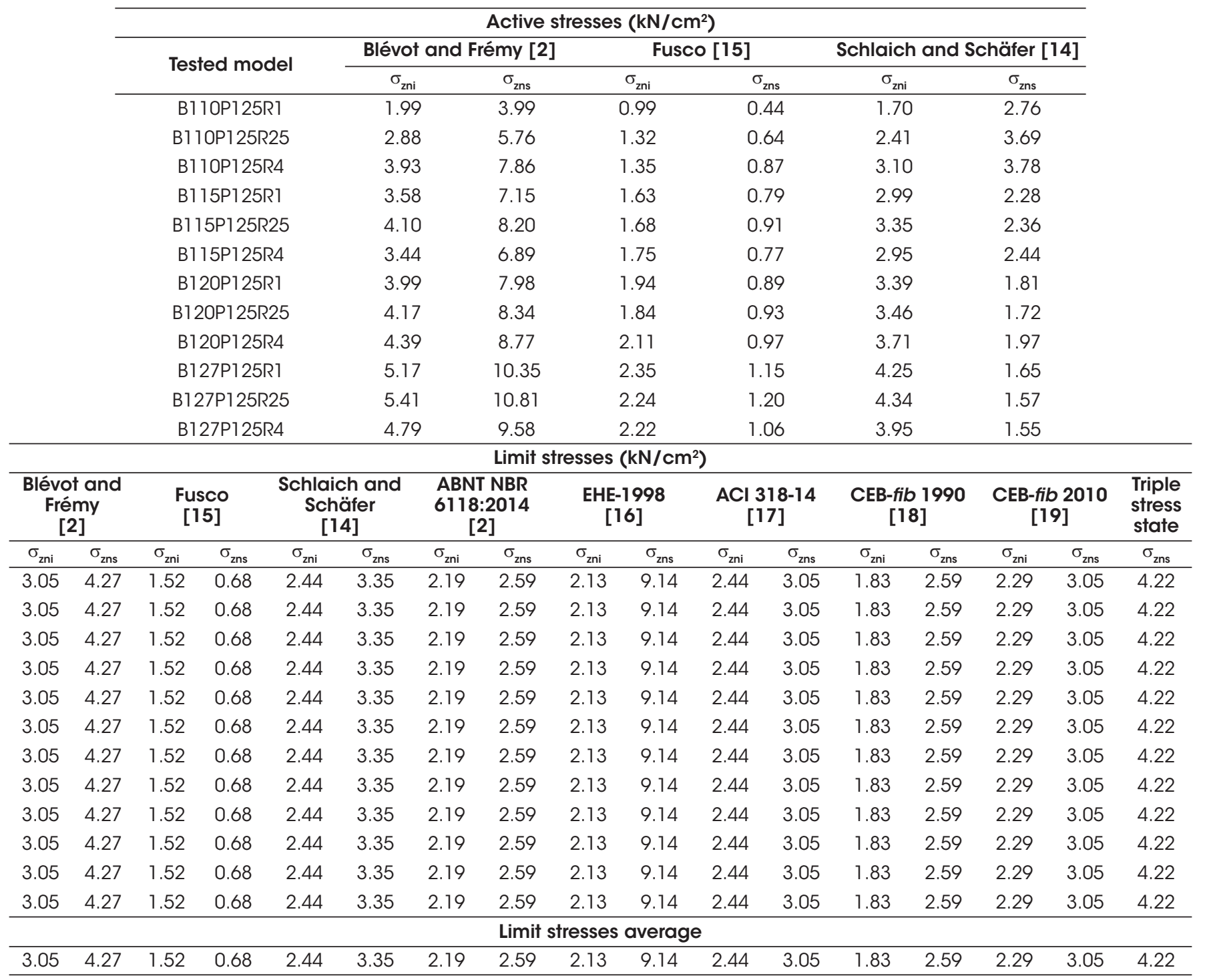

Table 32

Active stresses $\times$ Limits considered for Mesquita's tests [12]

\begin{tabular}{|c|c|c|c|c|c|c|c|c|c|c|c|c|c|c|c|c|}
\hline & & \multicolumn{13}{|c|}{ Active stresses $\left(\mathrm{kN} / \mathrm{cm}^{2}\right)$} & & \\
\hline & & \multirow{2}{*}{\multicolumn{2}{|c|}{$\begin{array}{l}\text { Tested } \\
\text { model }\end{array}$}} & \multicolumn{4}{|c|}{ Blévot and Frémy [2] } & \multicolumn{3}{|c|}{ Fusco [15] } & \multicolumn{4}{|c|}{ Schlaich and Schäfer [14] } & & \\
\hline & & & & \multicolumn{2}{|c|}{$\sigma_{\mathrm{zni}}$} & \multicolumn{2}{|c|}{$\sigma_{\mathrm{zns}}$} & $\sigma_{\mathrm{zni}}$ & \multicolumn{2}{|r|}{$\sigma_{\text {zns }}$} & \multicolumn{2}{|c|}{$\sigma_{\mathrm{zni}}$} & \multicolumn{2}{|c|}{$\sigma_{\text {zns }}$} & & \\
\hline & & & $M$ & \multicolumn{2}{|c|}{3.88} & 7.76 & & 1.92 & \multicolumn{2}{|r|}{0.86} & \multicolumn{2}{|c|}{3.47} & \multicolumn{2}{|c|}{5.38} & & \\
\hline \multicolumn{17}{|c|}{ Limit stresses $\left(\mathrm{kN} / \mathrm{cm}^{2}\right)$} \\
\hline \multicolumn{2}{|c|}{$\begin{array}{c}\text { Blévot and } \\
\text { Frémy } \\
\text { [2] }\end{array}$} & \multicolumn{2}{|c|}{$\begin{array}{c}\text { Fusco } \\
{[15]}\end{array}$} & \multicolumn{2}{|c|}{$\begin{array}{c}\text { Schlaich and } \\
\text { Schäfer } \\
{[14]}\end{array}$} & \multicolumn{2}{|c|}{$\begin{array}{c}\text { ABNT NBR } \\
6118: 2014 \\
{[2]}\end{array}$} & \multicolumn{2}{|c|}{$\begin{array}{c}\text { EHE-1998 } \\
{[16]}\end{array}$} & \multicolumn{2}{|c|}{$\begin{array}{c}\mathrm{ACl} 318-14 \\
{[17]}\end{array}$} & \multicolumn{2}{|c|}{$\begin{array}{c}\text { CEB-fib } 1990 \\
{[18]}\end{array}$} & \multicolumn{2}{|c|}{$\begin{array}{c}\text { CEB-fib } 2010 \\
{[19]}\end{array}$} & $\begin{array}{l}\text { Triple } \\
\text { stress } \\
\text { state }\end{array}$ \\
\hline$\sigma_{\mathrm{zni}}$ & $\sigma_{\text {zns }}$ & $\sigma_{\mathrm{zni}}$ & $\sigma_{\mathrm{zns}}$ & $\sigma_{\mathrm{zni}}$ & $\sigma_{\mathrm{zns}}$ & $\sigma_{\mathrm{zni}}$ & $\sigma_{\mathrm{zns}}$ & $\sigma_{\mathrm{zni}}$ & $\sigma_{\mathrm{zns}}$ & $\sigma_{\mathrm{zni}}$ & $\sigma_{\mathrm{zns}}$ & $\sigma_{\mathrm{zni}}$ & $\sigma_{\mathrm{zns}}$ & $\sigma_{\mathrm{zni}}$ & $\sigma_{\mathrm{zns}}$ & $\sigma_{\mathrm{zns}}$ \\
\hline 4.22 & 5.91 & 2.11 & 0.94 & 3.38 & 4.64 & 3.04 & 3.59 & 2.95 & 12.66 & 3.38 & 4.22 & 2.53 & 3.59 & 3.17 & 4.22 & 5.68 \\
\hline
\end{tabular}




\section{Table 33}

Active stresses $\times$ Limits considered for Cao and Bloodworth's [13] tests

\begin{tabular}{|c|c|c|c|c|c|c|c|c|c|c|c|c|c|c|}
\hline \multicolumn{14}{|c|}{ Active stresses $\left(\mathrm{kN} / \mathrm{cm}^{2}\right)$} & \\
\hline \multirow{2}{*}{\multicolumn{3}{|c|}{ Tested model }} & \multicolumn{3}{|c|}{ Blévot and Frémy [2] } & \multicolumn{4}{|c|}{ Fusco [15] } & \multicolumn{4}{|c|}{ Schlaich and Schäfer [14] } & \\
\hline & & & \multicolumn{2}{|c|}{$\sigma_{\mathrm{zni}}$} & $\sigma_{\mathrm{zns}}$ & \multicolumn{2}{|c|}{$\sigma_{\mathrm{zni}}$} & \multicolumn{2}{|c|}{$\sigma_{\mathrm{zns}}$} & \multicolumn{2}{|c|}{$\sigma_{\mathrm{zni}}$} & \multicolumn{2}{|l|}{$\sigma_{\mathrm{zns}}$} & \\
\hline \multicolumn{3}{|c|}{ B4A1 } & \multicolumn{2}{|c|}{6.25} & 6.64 & \multicolumn{2}{|c|}{0.80} & \multicolumn{2}{|c|}{3.69} & \multicolumn{2}{|c|}{4.09} & \multicolumn{2}{|c|}{1.18} & \\
\hline \multicolumn{3}{|c|}{ B4A2 } & \multicolumn{2}{|c|}{4.37} & 4.64 & \multicolumn{2}{|c|}{0.74} & \multicolumn{2}{|c|}{2.58} & \multicolumn{2}{|c|}{3.03} & \multicolumn{2}{|c|}{1.10} & \\
\hline \multicolumn{3}{|c|}{ B4A3 } & \multicolumn{2}{|c|}{6.02} & 6.39 & \multicolumn{2}{|c|}{1.24} & \multicolumn{2}{|c|}{3.55} & \multicolumn{2}{|c|}{4.34} & \multicolumn{2}{|l|}{1.84} & \\
\hline \multicolumn{3}{|c|}{ B4A4 } & \multicolumn{2}{|c|}{6.23} & 6.62 & \multicolumn{2}{|c|}{1.42} & & & 4.5 & & 2.10 & & \\
\hline & B4A5 & & 6.04 & & 6.41 & & 67 & & & 4.6 & & 2.49 & & \\
\hline & B4B2 & & 6.59 & & 5.38 & & 96 & & & 4.5 & & 1.10 & & \\
\hline & B4B3 & & 8.01 & & 5.67 & & .03 & & & 5.3 & & 1.03 & & \\
\hline & & & & & Limit st & esses & $\mathrm{kN} / \mathrm{cm}$ & & & & & & & \\
\hline $\begin{array}{c}\text { Fus } \\
{[1}\end{array}$ & $\begin{array}{l}\text { sco } \\
5]\end{array}$ & $\begin{array}{r}\text { Schla } \\
\text { Scl } \\
{[}\end{array}$ & $\begin{array}{l}\text { h and } \\
\text { affer } \\
4]\end{array}$ & $\begin{array}{r}\text { ABN } \\
6118 \\
{[}\end{array}$ & $\begin{array}{l}\text { NBR } \\
2014 \\
]\end{array}$ & $\begin{array}{c}\text { EHE- } \\
\text { [ }\end{array}$ & $\begin{array}{l}998 \\
6]\end{array}$ & $\mathrm{ACl}$ & $\begin{array}{l}\text { 8-14 } \\
]\end{array}$ & $\begin{array}{c}\text { CEB- } f \\
{[}\end{array}$ & B] 1990 & $\begin{array}{r}\text { CEB- } f \\
{[}\end{array}$ & $\begin{array}{l}2010 \\
\text { ] }\end{array}$ & $\begin{array}{l}\text { Triple } \\
\text { stress } \\
\text { state }\end{array}$ \\
\hline$\sigma_{\mathrm{zni}}$ & $\sigma_{\mathrm{zns}}$ & $\sigma_{\mathrm{zni}}$ & $\sigma_{\mathrm{zns}}$ & $\sigma_{\mathrm{zni}}$ & $\sigma_{\mathrm{zns}}$ & $\sigma_{\mathrm{zni}}$ & $\sigma_{\mathrm{zns}}$ & $\sigma_{\mathrm{zni}}$ & $\sigma_{\mathrm{zns}}$ & $\sigma_{\mathrm{zni}}$ & $\sigma_{\mathrm{zns}}$ & $\sigma_{\mathrm{zni}}$ & $\sigma_{\mathrm{zns}}$ & $\sigma_{\mathrm{zns}}$ \\
\hline 1.02 & 0.45 & 1.62 & 2.23 & 1.22 & 1.73 & 1.42 & 6.09 & 1.22 & 2.03 & 1.22 & 1.73 & 1.52 & 2.03 & 2.92 \\
\hline 1.09 & 0.48 & 1.74 & 2.40 & 1.3 & 1.85 & 1.53 & 6.54 & 1.31 & 2.18 & 1.31 & 1.85 & 1.64 & 2.18 & 3.12 \\
\hline 1.22 & 0.54 & 1.94 & 2.67 & 1.46 & 2.07 & 1.70 & 7.29 & 1.46 & 2.43 & 1.46 & 2.07 & 1.82 & 2.43 & 3.44 \\
\hline 1.22 & 0.54 & 1.95 & 2.68 & 1.46 & 2.07 & 1.71 & 7.32 & 1.46 & 2.44 & 1.46 & 2.07 & 1.83 & 2.44 & 3.45 \\
\hline 1.15 & 0.51 & 1.84 & 2.53 & 1.38 & 1.96 & 1.61 & 6.90 & 1.38 & 2.30 & 1.38 & 1.96 & 1.73 & 2.30 & 3.27 \\
\hline 1.28 & 0.57 & 2.05 & 2.82 & 1.54 & 2.18 & 1.79 & 7.68 & 1.54 & 2.56 & 1.54 & 2.18 & 1.92 & 2.56 & 3.60 \\
\hline 1.24 & 0.55 & 1.98 & 2.72 & 1.48 & 2.10 & 1.73 & 7.41 & 1.48 & 2.47 & 1.48 & 2.10 & 1.85 & 2.47 & 3.49 \\
\hline & & & & & Limit st & resses & averag & & & & & & & \\
\hline 1.17 & 0.52 & 1.88 & 2.58 & 1.41 & 1.99 & 1.64 & 7.03 & 1.41 & 2.34 & 1.41 & 1.99 & 1.76 & 2.34 & 3.33 \\
\hline
\end{tabular}

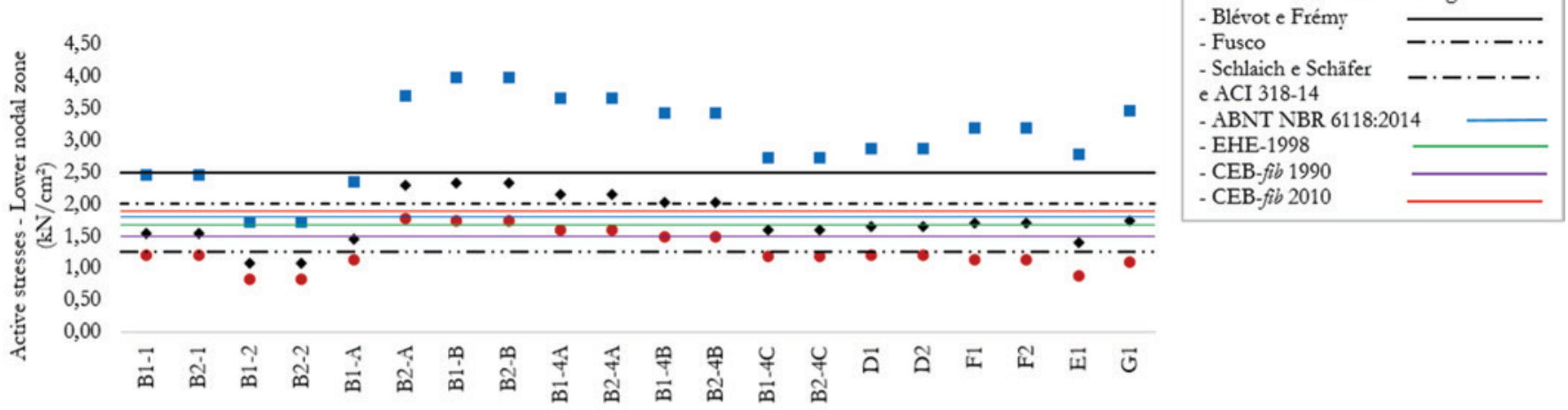

W Active stresses - Blévot e Frémy - Active stresses - Fusco • Active stresses - Schlaich e Schäfer

\section{Figure 7}

Models tested by Mautoni [5] $\times \sigma_{z \mathrm{ni}}$ 

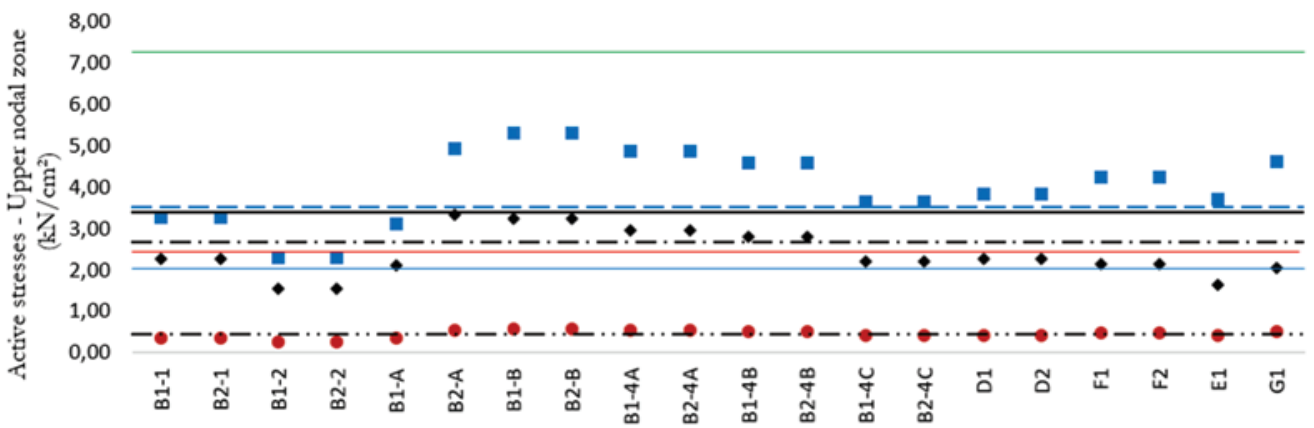

Limit stresses average: Blévot e Frémy

$\begin{array}{ll}\text { - Fusco } & -\cdots-\cdots-\cdots \\ \text { - Schlaich e Schäfer } & -\cdot-\cdot-\cdot-\end{array}$

ABNT NBR 6118:2014

e CEB-fib 1990

- EHE-1998

- ACI 318-14 e

CEB-fib 2010

- Triple stress

state

\section{- Active stresses - Blévot e Frémy $\quad$ Active stresses - Fusco $\quad$ Active stresses - Schlaich e Schäfer}

\section{Figure 8}

Models tested by Mautoni [5] $\times \sigma_{\mathrm{zns}}$

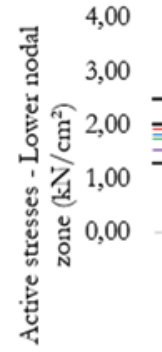

- Active stresses - Blévot e Frémy

\section{Figure 9}

Models tested by Fusco [6] $\times \sigma_{z \mathrm{zi}}$

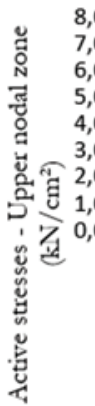

\section{8,00}

7,00

5,00

4,00
3,00

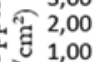

1,00

资 0,00

岁
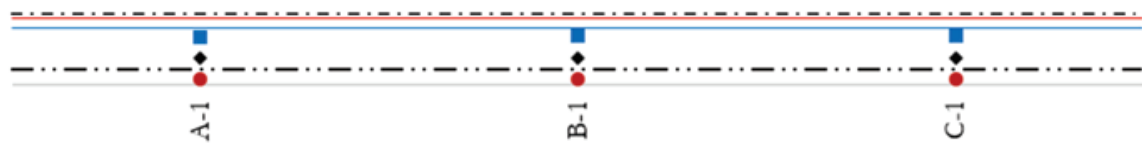

- Active stresses - Blévot e Frémy

- Active stresses - Fusco

- Active stresses - Schlaich e Schäfer
Limit stresses average:

- Blévot e Frémy

- Fusco

- Schlaich e Schäfer

e ACI 318-14

- ABNT NBR 6118:2014

- EHE-1998

- CEB-fib 1990

- CEB-fib 2010

\section{Figure 10}

Models tested by Fusco [6] $\times \sigma_{\text {zns }}$

\begin{tabular}{ll}
\multicolumn{2}{c}{ Limit stresses average: } \\
\cline { 2 - 2 } - Blévot e Frémy \\
- Fusco & $-\cdots-\cdots-\cdots$ \\
- Schlaich e Schäfer & $-\cdot-\cdot-\cdot-$ \\
- ABNT NBR 6118:2014 \\
e CEB-fib 1990 \\
- EHE-1998 \\
- ACI 318-14 e \\
CEB-fib 2010 \\
- Triple stress \\
state
\end{tabular}




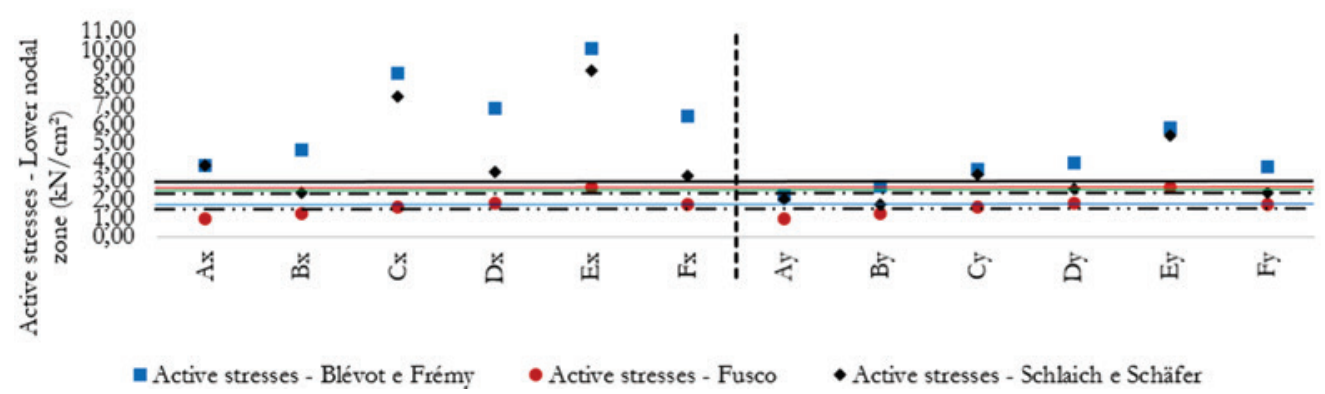

Limit stresses average:

Blévot e Frémy

Fusco

Schlaich e Schäfer

e ACI 318-14

- ABNT NBR 6118:2014

EHE-1998

- CEB-fib 1990

CEB-fib 2010

\section{Figure 11}

Models tested by Adebar et al. [4] $\times \sigma_{\text {zni }}$

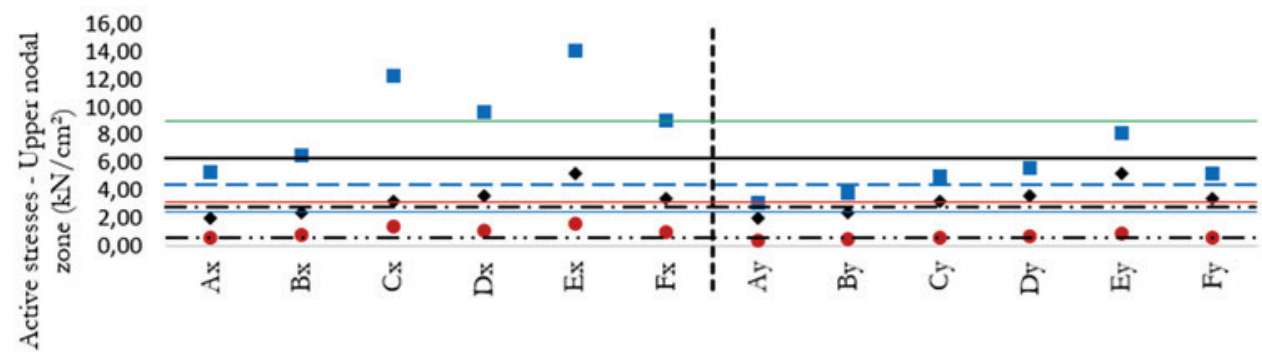

$\begin{array}{ll}\text { - Blévot e Frémy } & \\ \text { - Fusco } & -\cdots-\cdots-\cdots \\ \text { - Schlaich e Schäfer } & -\cdot-\cdot-\cdot- \\ \text { - ABNT NBR 6118:2014 } \\ \text { e CEB-fib 1990 } \\ \text { - EHE-1998 } \\ \text { - ACI 318-14 e } \\ \text { CEB-fib 2010 } \\ \text { - Triple stress } \\ \text { state }\end{array}$

a Active stresses - Blévot e Frémy $\quad$ Active stresses - Fusco • Active stresses - Schlaich e Schäfer

\section{Figure 12}

Models tested by Adebar et al. [4] $\times \sigma_{z n s}$

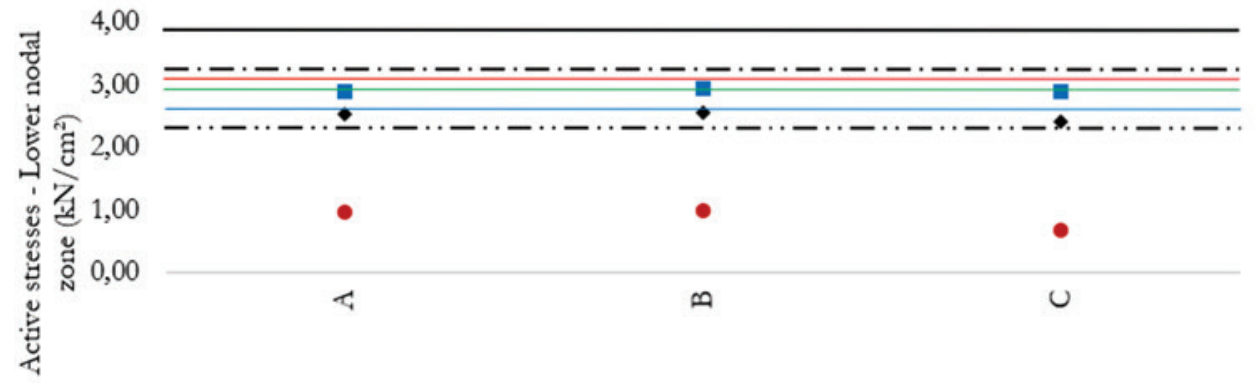

Limit stresses average:

- Blévot e Frémy

- Fusco

- Schlaich e Schäfer $\quad-\cdot-\cdot \cdot \cdot-$.

e ACI 318-14

- ABNT NBR 6118:2014

- EHE-1998

- CEB-fib 1990

- CEB-fib 2010

- Active stresses - Blévot e Frémy • Active stresses - Fusco • Active stresses - Schlaich e Schäfer

Figure 13

Models tested by Chan and Poh [7] $\times \sigma_{z n i}$ 

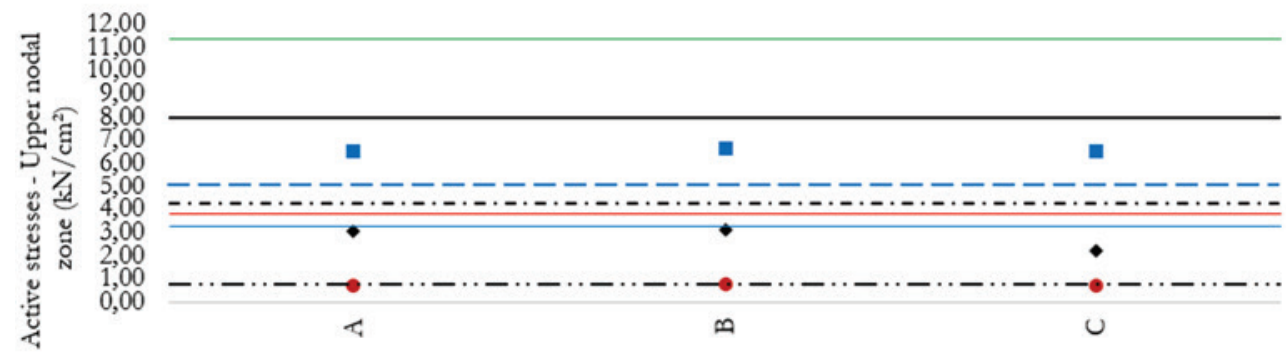

\begin{tabular}{ll}
\multicolumn{3}{c}{ Limit stresses average: } \\
\cline { 2 - 2 } - Blévot e Frémy \\
- Fusco & $-\cdots-\cdots-\cdots$ \\
- Schlaich e Schäfer & $-\cdots-\cdot-\cdot-$ \\
- ABNT NBR 6118:2014 \\
e CEB-fib 1990 \\
- EHE-1998 \\
- ACI 318-14 e \\
CEB-fib 2010 \\
- Triple stress \\
state
\end{tabular}

- Active stresses - Blévot e Frémy

- Active stresses - Fusco

- Active stresses - Schlaich e Schäfer

\section{Figure 14}

Models tested by Chan and Poh [7] $\times \sigma_{z n s}$
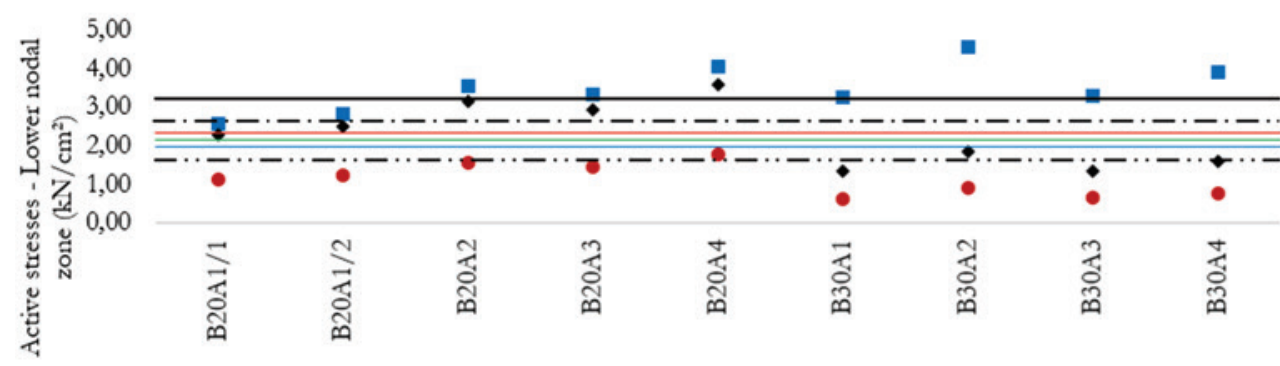

- Active stresses - Blévot e Frémy

- Active stresses - Fusco

- Active stresses - Schlaich e Schäfer

\section{Figure 15}

Moldels tested by Miguel $[8] \times \sigma_{z n i}$
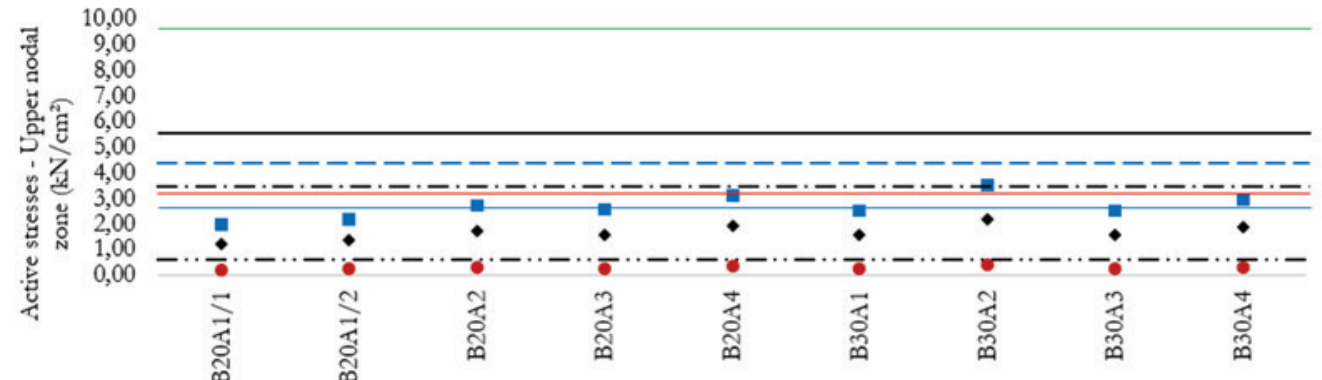

Limit stresses average:

Blévot e Frémy

- Fusco

$\overline{-\cdots-\cdots-\cdots}$

- Schlaich e Schäfer

$-\cdot-\cdot \cdot \cdot \cdot$

e ACI 318-14

- ABNT NBR 6118:2014

- EHE-1998

- CEB-fib 1990

- CEB-fib 2010

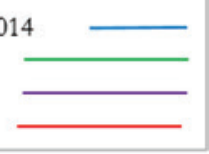

\section{Figure 16}

Models tested by Miguel [8] $\times \sigma_{\text {zns }}$ 

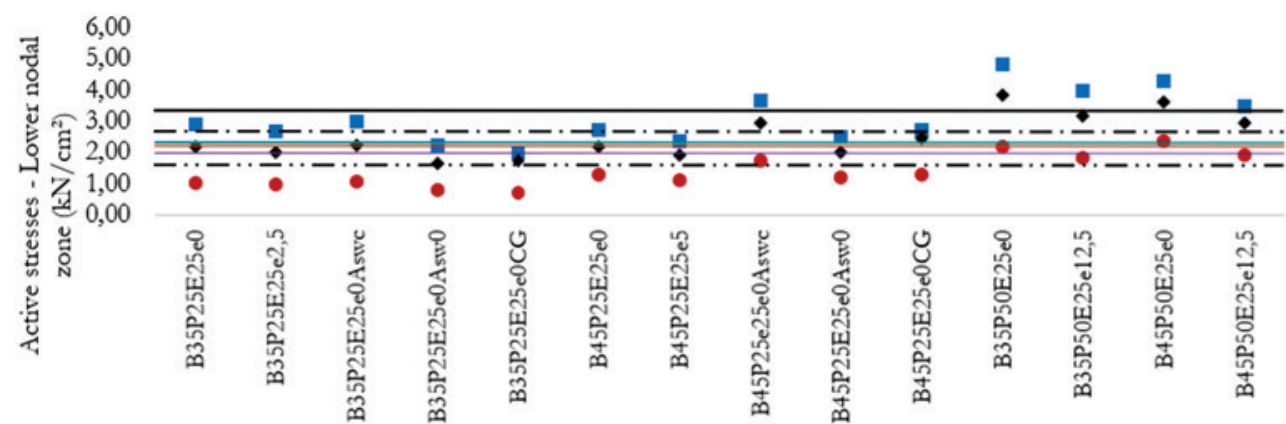

-

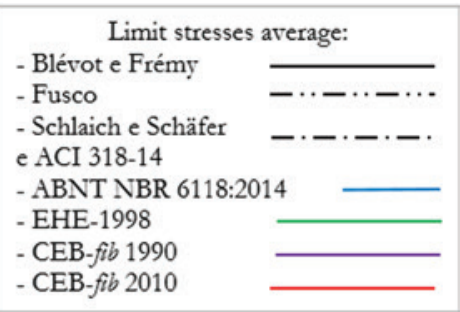

- Active stresses - Blévot e Frémy

- Active stresses - Fusco

- Active stresses - Schlaich e Schäfer

\section{Figure 17}

Models tested by Delalibera and Giongo [9] $\times \sigma_{z n i}$

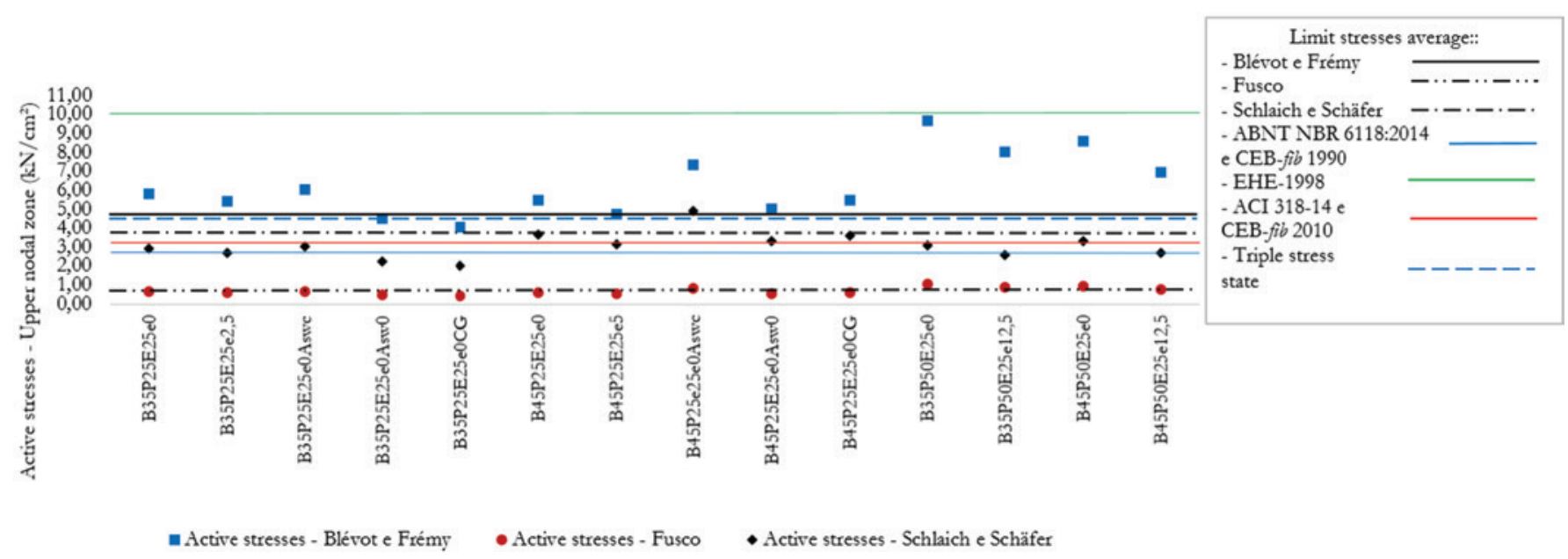

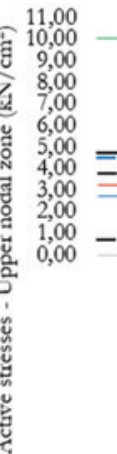

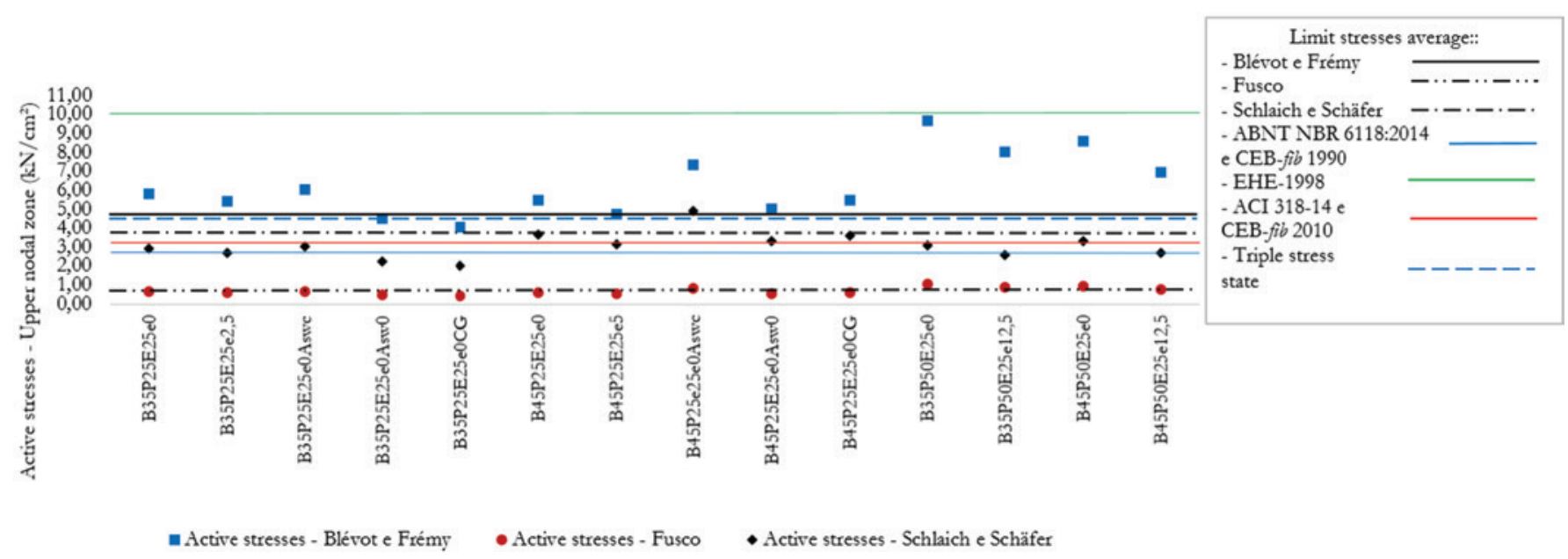

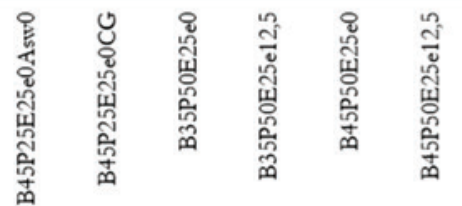

- CEB-fib 2010

\section{Figure 18}

Models tested by Delalibera and Giongo [9] $\times \sigma_{z n s}$
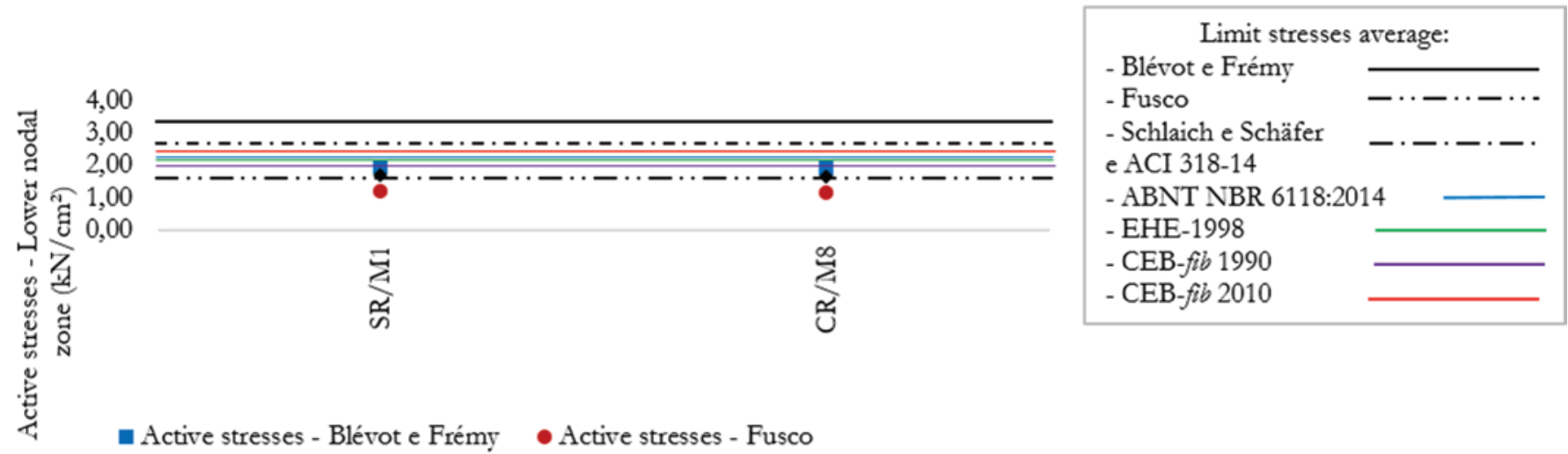

- Active stresses - Blévot e Frémy - Active stresses - Fusco

- Active stresses - Schlaich e Schäfer

\section{Figure 19}

Models tested by Barros [10] $\times \sigma_{z n i}$ 

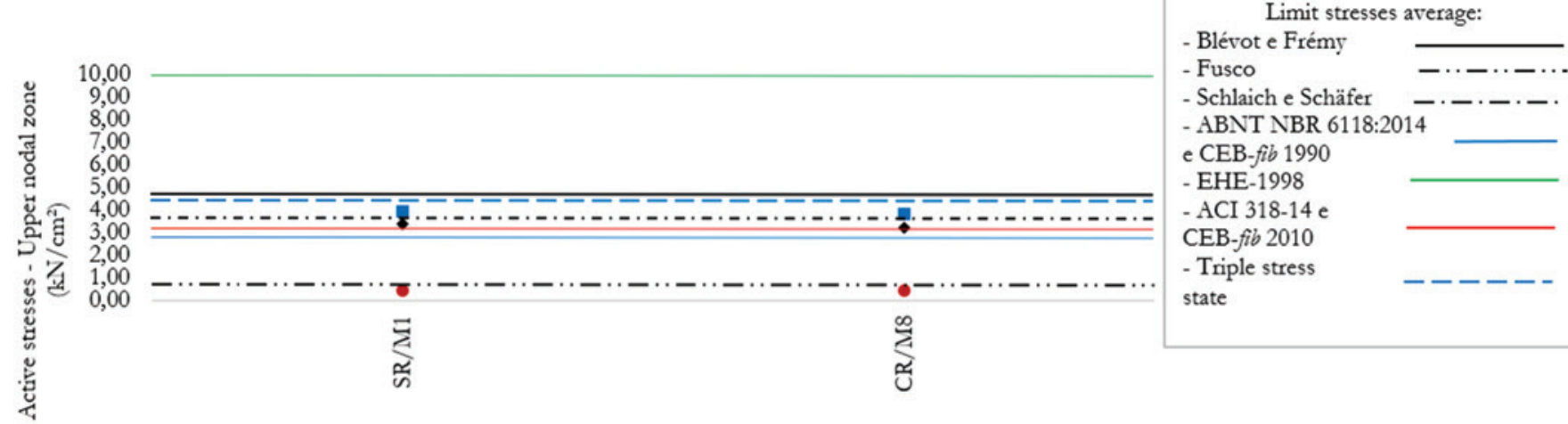

Active stresses - Blévot e Frémy

- Active stresses - Fusco

- Active stresses - Schlaich e Schäfer

\section{Figure 20}

Models tested by Barros [10] $\times \sigma_{\text {zns }}$
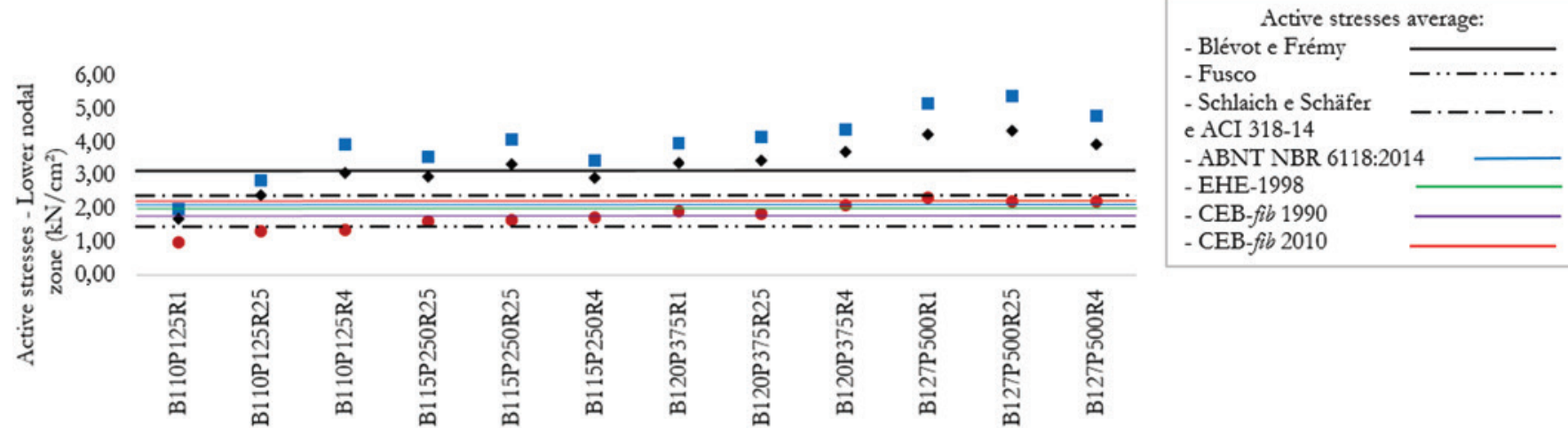

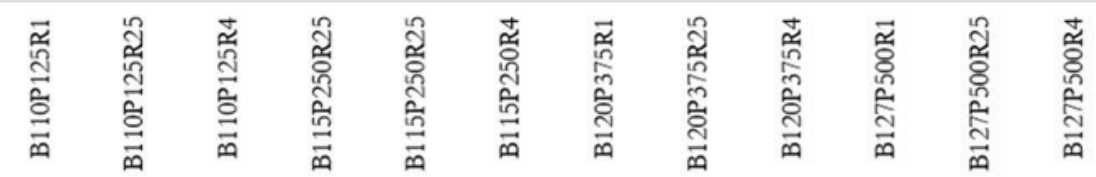

- Active stresses - Blévot e Frémy $\quad$ Active stresses - Fusco - Active stresses - Schlaich e Schäfer

Figure 21

Models tested by Munhoz [11] $\times \sigma_{z n i}$

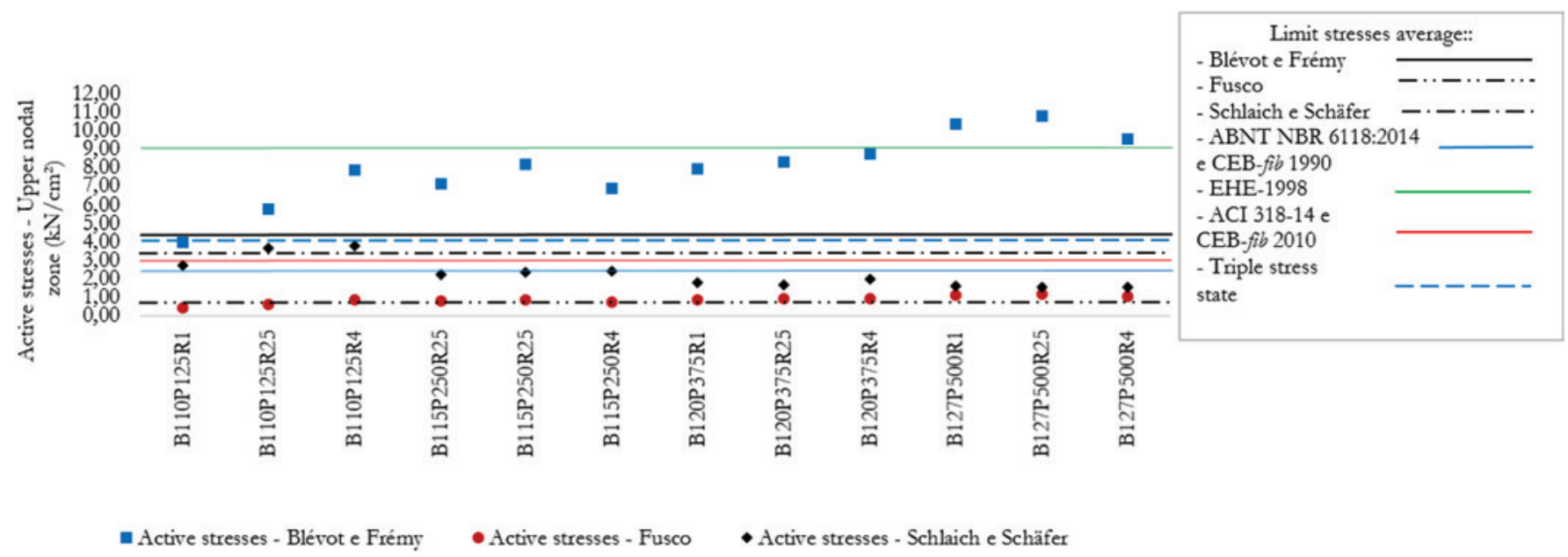

\section{Figure 22}

Models tested by Munhoz [11] $\times \sigma_{\text {zns }}$ 


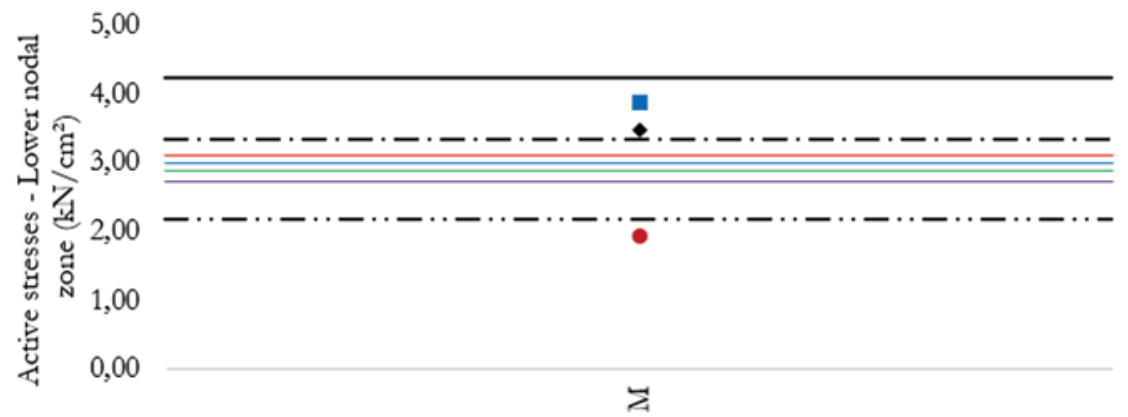

\begin{tabular}{|ll}
\hline \multicolumn{3}{|c}{ Limit estresses average: } \\
\cline { 2 - 2 } - Blévot e Frémy & $-\cdots-\cdots-\cdots$ \\
- Fusco & $-\cdots-\cdot-\cdot \cdot$ \\
- Schlaich e Schäfer & $-\cdot-\cdot-\cdot \cdot$ \\
e ACI 318-14 & \\
- ABNT NBR 6118:2014 \\
- EHE-1998 \\
- CEB-fib 1990 \\
- CEB-fib 2010 \\
\hline
\end{tabular}

n Active stresses - Blévot e Frémy $\quad$ Active stresses - Fusco

- Active stresses - Schlaich e Schäfer

\section{Figure 23}

Models tested by Mesquita [12] $\times \sigma_{z n i}$

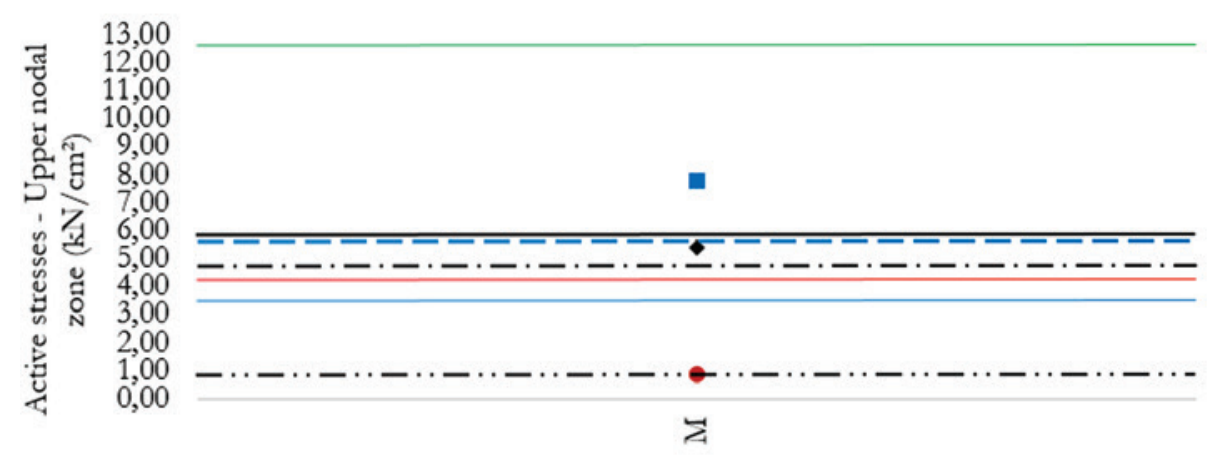

Limite stresses average:

- Blévot e Frémy

- Fusco

- Schlaich e Schäfer

- ABNT NBR 6118:2014

e CEB-fib 1990

- EHE-1998

- ACI 318-14 e

CEB-fib 2010

- Triple stress

state

- Active stresses - Blévot e Frémy - Active stresses - Fusco

- Active stresses - Schlaich e Schäfer

\section{Figure 24}

Models tested by Mesquita [12] $\times \sigma_{\mathrm{zns}}$

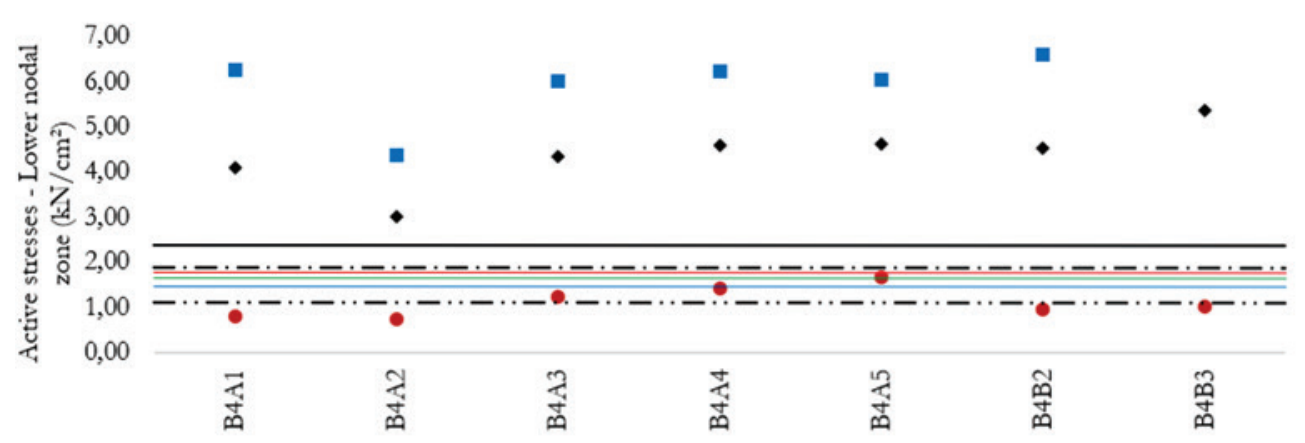

Limit stresses average:

Blévot e Frémy

- Fusco

- Schlaich e Schäfer

e ACI 318-14

- ABNT NBR 6118:2014

- EHE-1998

- CEB-fib 1990

- CEB-fib 2010

- Active stresses - Blévot e Frémy

- Active stresses - Fusco

- Active stresses - Schlaich e Schäfer

\section{Figure 25}

Models tested by Cao and Bloodworth [13] $\times \sigma_{z n i}$ 


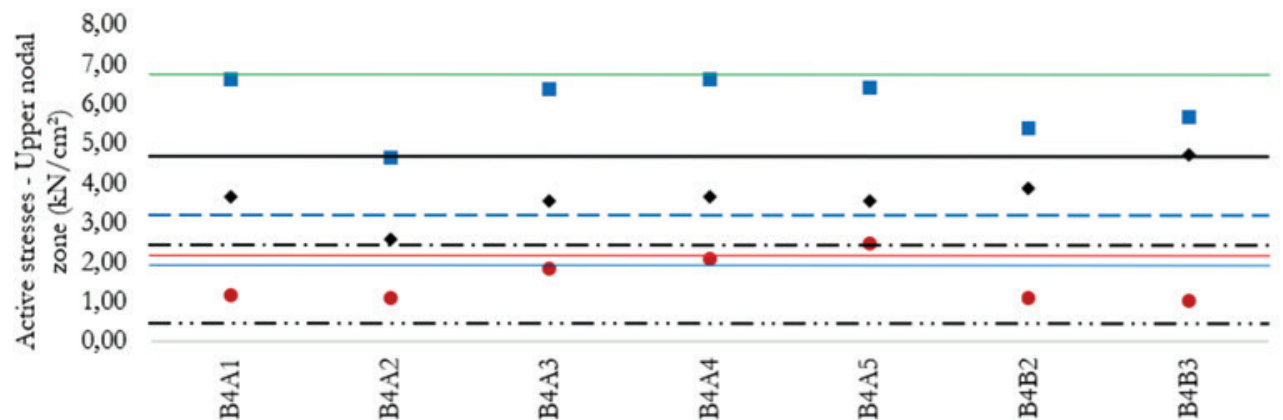

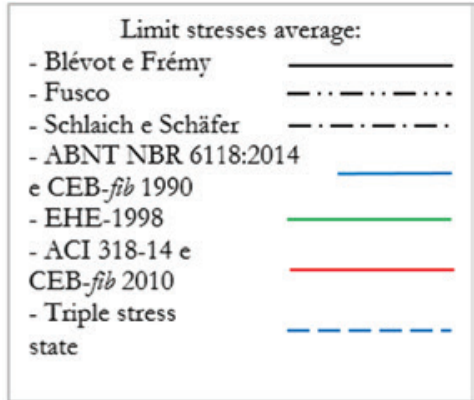

- Active stresses - Blévot e Frémy - Active stresses - Fusco - Active stresses - Schlaich e Schäfer

\section{Figure 26}

Models tested by Cao and Bloodworth [13] $\times \sigma_{\text {zns }}$

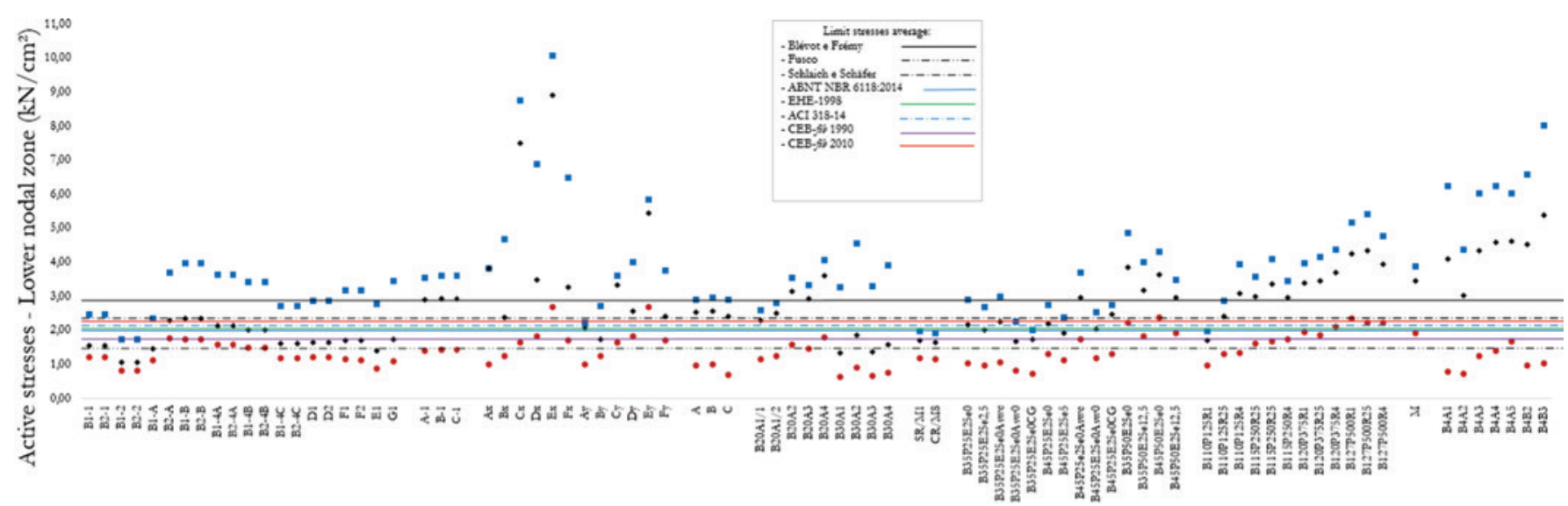

\section{Figure 27}

Models tested $\times \sigma_{\mathrm{zni}}$

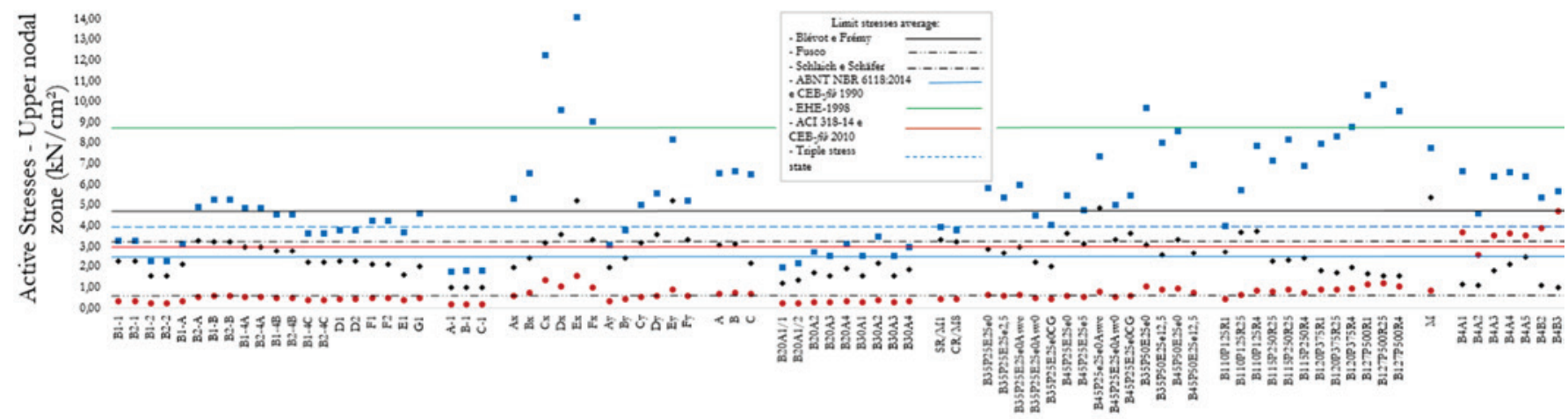

- Active stresses - Blévot e Frémy $\quad$ - Active stresses - Fusco · Active stresses - Schlaich e Schäfer

\section{Figure 28}

Models tested $\times \sigma_{\mathrm{zns}}$ 
that were much smaller than the limit value presented by the Spanish standard.

By evaluating the graphs of stresses (excluding the values obtained by using the model proposed by Fusco [15]) it is shown that, for the lower nodal area, the results fit better with the limits suggested by the CEB-fib [18], while for the upper nodal zone, the results fit better with the limits indicated by Schlaich and Schäfer [14] and by the triple stress state proposed by the authors of this work. This confirms that, in addition with the analysis of Figure [4] the node representation for the upper nodal zone suggested by Schlaich and Schäfer [14] is best characterized by the triple stress state. Thus, it is suggested that for the upper nodal zone the effect of the multiaxial stress state should be considered.

Different areas of cross sections of columns, existence of reinforcement to absorb tensile stresses on the struts, cross section of the pile and column reinforcement ratio, affect the values of the operating stresses and are not contemplated by any calculation model presented so far, being possible source for future research.

\section{Acknowledgments}

To The College of Civil Engineering linked to the Federal University of Uberlândia and to the company Gerdau S.A., for the support to the research.

\section{References}

[1] BLÉVOT, J. Semelles en béton armé sur pieux. Institut de Recherches Appliquées du Béton Armé. Paris, m. 111-112, 1957.

[2] BLÉVOT, J.; FRÉMY, R. Semelles sur pieux. Analles d'Institut Techique du Bâtiment et des Travaux Publics. Paris, v.20, n. 230, 1967, p. 223-295.

[3] ASSOCIAÇÃO BRASILEIRA DE NORMAS TÉCNICAS (2014). ABNT NBR 6118:2014 - Projeto de estruturas de concreto. Rio de Janeiro: ABNT 2014.

[4] ADEBAR, P.; KUCHMA, D. COLLINS, M. P. Strut-and-tie models for design of pile caps: an experimental study. $\mathrm{ACl}$ Journal, v.87, 1990; p.81-91.

[5] MAUTONI, M. Blocos sobre dois apoios, São Paulo, Grêmio Politécnico, 1972, 89 p.

[6] FUSCO, P. B. Investigação experimental sobre o valor limite $\mathrm{T}_{\text {wu }}$ das tensões de cisalhamento no concreto estrutural, São Paulo, 1985.

[7] CHAN, T. K. POH, C. K. Behavior of precast reinforced concrete pile caps. Construction and building materials, v.14, n.2, 2000; p.73-78.

[8] MIGUEL, M. G. Análise numérica e experimental de blocos sobre três estacas, São Carlos, 2000, Tese (doutorado) Escola de Engenharia de São Carlos, Universidade de São Paulo, $242 \mathrm{p}$.

[9] DELALIBERA, R. G.; GIONGO, J. S. Deformação nas diagonais comprimidas em blocos sobre duas estacas. Revista IBRACON de estruturas e materiais. V1, n.2 (junho 2008), p. 121-157.

[10] BARROS, R. Análise numérica e experimental de blocos de concreto armado sobre duas estacas com cálice externo, par- cialmente embutido e embutido utilizado na ligação pilar-fundação, São Carlos, 2013, Tese (doutorado) - Escola de Engenharia de São Carlos, Universidade de São Paulo, 355 p.

[11] MUNHOZ, F. S. Análise experimental e numérica de blocos rígidos sobre duas estacas com pilares de seções quadradas e retangulares e diferentes taxas de armadura, São Carlos, 2014, Tese (doutorado) - Escola de Engenharia de São Carlos, Universiadade de São Paulo, 358 p.

[12] MESQUITA, A. C. A influência da ligação pilar-bloco nos mecanismos de rupture de blocos de fundação sobre duas estacas, Goiânia, 2015, Dissertação (mestrado) - Universidade Federal de Goiás, 165 p.

[13] CAO, J.; BLOODWORTH, A. G. Shear capacity of reinforced concrete pile caps. At IABSE (International Associatoin for bridge and structural engineering). Germany, 2007.

[14] SCHLAICH, J.; SCHÄFER, K. Design and detailing of structural concrete using strut-and-tie models, The Structural Engineer, v.69, n.6, 1991, p. 113-125.

[15] FUSCO, P. B. Técnicas de armar estruturas de concreto, 2 ed, São Paulo-SP, Editora Pini LTDA, 2013, 395 p.

[16] COMISÍON PERMANETE DEL HERMIGÓN (1998). Ministério de Fomento. Centro de Publicaciones. Instricción de Hormigón Estructural (EHE), Madrid, 1998.

[17] AMERICAN CONCRETE INSTITUTE 920140. Building code requirements for structural concrete (ACI 318-14). Detroit, USA.

[18] COMITE EURO-INTERNACIONAL DU BÉTON (1990). CEB-FIB Model Code. Paris, 1990.

[19] COMITE EURO-INTERNACIONAL DU BÉTON (2010). CEB-FIB Model code prepared by special activity group 5 . Paris, 2010.

[20] INSTITUTO BRASILEIRO DO CONCRETO. ABNT NBR 6118:2014 Comentários e Exemplos de Aplicação. 1 ed, São Paulo-SP, 2015, 480 p. 